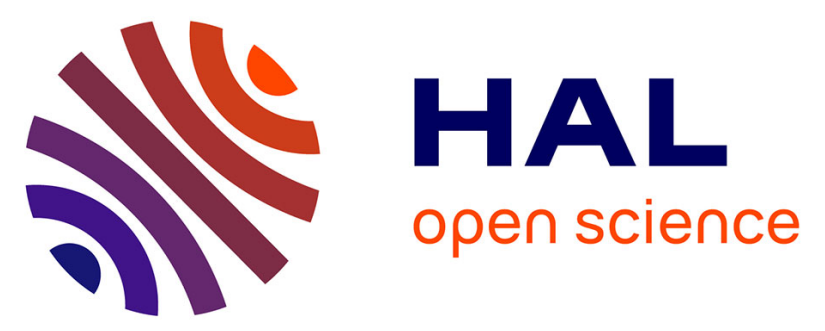

\title{
Towards a climatology of stratospheric bromine monoxide from SCIAMACHY limb observations
}

N. Sheode, B.-M. Sinnhuber, A. Rozanov, J. P. Burrows

\section{To cite this version:}

N. Sheode, B.-M. Sinnhuber, A. Rozanov, J. P. Burrows. Towards a climatology of stratospheric bromine monoxide from SCIAMACHY limb observations. Atmospheric Chemistry and Physics Discussions, 2006, 6 (4), pp.6431-6466. hal-00301951

\section{HAL Id: hal-00301951 \\ https://hal.science/hal-00301951}

Submitted on 13 Jul 2006

HAL is a multi-disciplinary open access archive for the deposit and dissemination of scientific research documents, whether they are published or not. The documents may come from teaching and research institutions in France or abroad, or from public or private research centers.
L'archive ouverte pluridisciplinaire HAL, est destinée au dépôt et à la diffusion de documents scientifiques de niveau recherche, publiés ou non, émanant des établissements d'enseignement et de recherche français ou étrangers, des laboratoires publics ou privés. 
Atmos. Chem. Phys. Discuss., 6, 6431-6466, 2006

www.atmos-chem-phys-discuss.net/6/6431/2006/

(C) Author(s) 2006. This work is licensed

under a Creative Commons License.

\section{BrO from}

SCIAMACHY

N. Sheode et al.

\section{Towards a climatology of stratospheric bromine monoxide from SCIAMACHY limb observations}

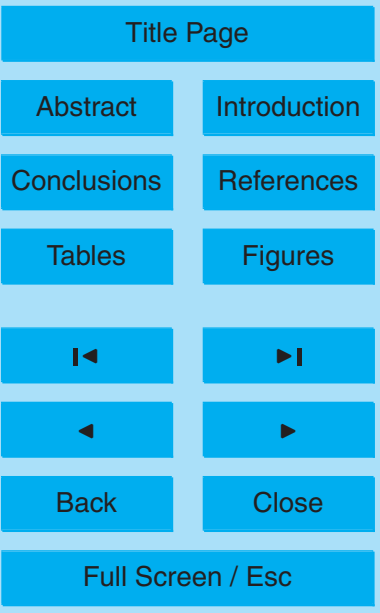

N. Sheode, B.-M. Sinnhuber, A. Rozanov, and J. P. Burrows

Institute of Environmental Physics, University of Bremen, Bremen, Germany

Received: 19 April 2006 - Accepted: 31 May 2006 - Published: 13 July 2006

Correspondence to: N. Sheode (nsheode @iup.physik.uni-bremen.de)

Full Screen / Esc

Printer-friendly Version

Interactive Discussion 


\section{Abstract}

Retrievals of stratospheric bromine monoxide $(\mathrm{BrO})$ profiles from two years of limb measurements from the Scanning Imaging Absorption Spectrometer for Atmospheric Chartography (SCIAMACHY) instrument onboard ENVISAT are analysed and a global

5 climatology of stratospheric $\mathrm{BrO}$ is prepared. A comparison of the SCIAMACHY BrO retrievals with a set of four balloon-borne BrO profiles shows mean relative differences in the altitude range from 18 to $30 \mathrm{~km}$ between $+17 \%$ and $-42 \%$. The SCIAMACHY $\mathrm{BrO}$ observations provide for the first time a picture of the seasonal variation of stratospheric $\mathrm{BrO}$ on a global scale. At mid-latitudes of both hemispheres $\mathrm{BrO}$ shows a strong seasonal cycle with a maximum in winter and a minimum in summer. The seasonal variation of $\mathrm{BrO}$ is closely correlated with changes in nitrogen dioxide $\left(\mathrm{NO}_{2}\right)$, confirming our present understanding of gas phase bromine chemistry. Using the SCIAMACHY BrO observations together with the calculated bromine partitioning from a photochemical model constrained by the SCIAMACHY $\mathrm{NO}_{2}$ observations, the total 15 stratospheric bromine loading is estimated to be $18.5 \pm 4 \mathrm{pptv}$. This indicates a contribution of about $3.5 \pm 4$ pptv from short lived bromine species in addition to methyl bromide and the halons.

\section{Introduction}

Halogen compounds containing chlorine and bromine play a dominant role in the depletion of stratospheric ozone. Inorganic bromine compounds have a potential to cause far greater ozone losses at per molecule level than their chlorine counterparts. Despite their important role in the ozone destruction process, there are very few measurements of inorganic bromine species in the stratosphere. $\mathrm{BrONO}_{2}$ and $\mathrm{BrCl}$ have never been measured. There exist only few measurements of $\mathrm{HBr}$ and only upper limit measure-

\section{BrO from SCIAMACHY}

N. Sheode et al.

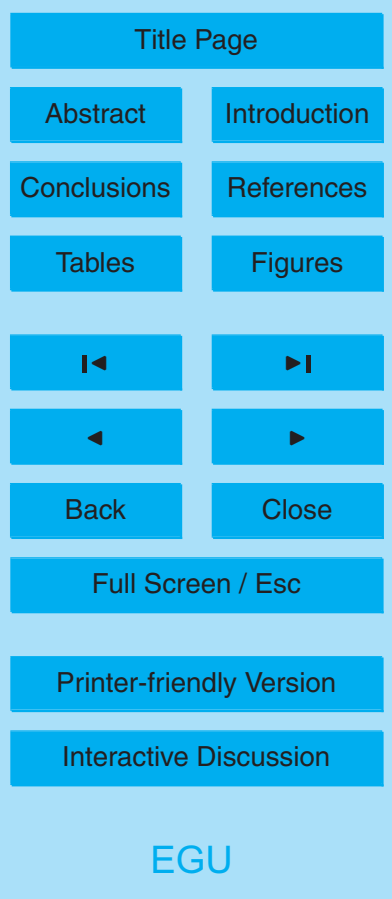


is bromine monoxide ( $\mathrm{BrO})$.

$\mathrm{BrO}$ has been measured in-situ by resonance fluorescence spectroscopy from both aircraft (Brune et al., 1989; Toohey et al., 1990; Avallone et al., 1995) and balloon (McKinney et al., 1997). BrO profiles have also been measured from balloon borne 5 UV-visible spectroscopy (Pundt et al., 2002; Harder et al., 1998; Dorf et al., 2005). Ground based UV-visible spectroscopy (Carroll et al., 1989; Solomon et al., 1989; Fish et al., 1997; Richter et al., 1999; Otten et al., 1998; Frieß et al., 1999; Sinnhuber et al., 2002; Schofield et al., 2004) has been used to measure BrO slant column densities. BrO column density measurements have also been done from space by 10 the Global Ozone Monitoring Experiment (GOME) instrument (e.g., Wagner and Platt, 1998; Richter et al., 2002). SCIAMACHY onboard ENVISAT provides the first global observations of stratospheric BrO profiles. First results of SCIAMACHY BrO observations for a 10 day period in September 2002 have been reported by Sinnhuber et al. (2005). Here we present now an analysis of the SCIAMACHY BrO observations over a period of two years which allows a first global view on the seasonal variation of stratospheric BrO.

The paper is organised in the following way. Section 2 reviews briefly our present understanding of the stratospheric bromine chemistry. In Sect. 3, our BrO retrieval method is presented along with sensitivity studies. In order to validate our SCIAMACHY $\mathrm{BrO}$ retrievals, a first comparison with balloon-borne BrO profiles is performed. Section 4 introduces the photochemical model used in this study along with a discussion on the partitioning of bromine species obtained from the 1-D model. Section 5 discusses the results of the two years of BrO climatology. Section 6 presents our estimate of the stratospheric $\mathrm{Br}_{\mathrm{y}}$ (calculated using the inorganic method) and the total bromine loading. Finally conclusion is given in Sect. 7.

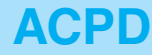

$6,6431-6466,2006$

\section{BrO from SCIAMACHY}

N. Sheode et al.

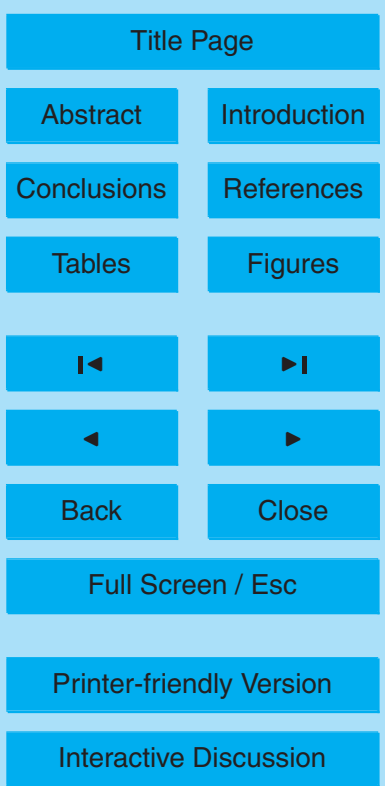

EGU 


\section{Stratospheric Bromine Chemistry}

The primary sources of bromine in the stratosphere are natural and anthropogenic methyl bromide and anthropogenically produced halons released at the Earth's surface. Very short lived bromine substances (VSLS) like $\mathrm{CH}_{2} \mathrm{Br}_{2}$ and $\mathrm{CH}_{2} \mathrm{BrCl}$ also contribute 5 to the stratospheric bromine loading. It has also been proposed that another short lived bromine species namely bromoform $\left(\mathrm{CHBr}_{3}\right)$ could make a contribution of up to 1 pptv to stratospheric bromine (Dvortsov et al., 1999; Sturges et al., 2000; Nielsen and Douglass, 2001; Sinnhuber and Folkins, 2005). Volcanic plumes could also make a contribution to the stratospheric bromine (Bobrowski et al., 2003). However the contribution of volcanic eruptions to the stratospheric bromine is unclear at present. Afe et al. (2004), using retrievals from GOME and SCIAMACHY, found no indications of enhanced $\mathrm{BrO}$ during volcanic eruptions. The organic sources of bromine are converted to inorganic forms $\left(\mathrm{Br}_{\mathrm{y}}=\mathrm{Br}, \mathrm{BrO}, \mathrm{BrONO}_{2}, \mathrm{HOBr}, \mathrm{HBr}, \mathrm{BrCl}\right)$ by photolysis or reactions with $\mathrm{OH}$ radicals at higher altitudes in the troposphere and stratosphere which then 15 subsequently participate in ozone destruction cycles. $\mathrm{Br}$ and $\mathrm{BrO}$ are called as reactive species while $\mathrm{BrONO}_{2}, \mathrm{HOBr}, \mathrm{HBr}$ and $\mathrm{BrCl}$ are called as reservoir species. These inorganic bromine species participate in the catalytic destruction of ozone.

An important but still unresolved question is the total bromine loading in the stratosphere. Accurate information of the total bromine in the stratosphere is important to

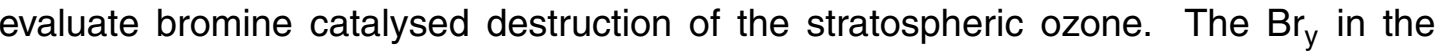
stratosphere can be estimated indirectly from the measurements of organic source gases in the stratosphere (organic method) (Schauffler et al., 1998; Wamsley et al., 1998) or by using the stratospheric $\mathrm{BrO}$ measurements along with a modeled $\mathrm{BrO} / \mathrm{Br}_{\mathrm{y}}$ ratio (Pfeilsticker et al., 2000; Harder et al., 2000; Sinnhuber et al., 2002, 2005) (inorganic method). For early 1999 , for example, the estimated volume mixing ratio of total bromine at $25 \mathrm{~km}$ in air of 5.6-year mean age was $18.4(+1.8,-1.5)$ pptv based on the organic method and $21.5 \pm 3$ pptv using the inorganic method (WMO, 2002, Figs. 326). The offset in the two methods allows for a possibility of a contribution of around

\section{BrO from SCIAMACHY}

N. Sheode et al.

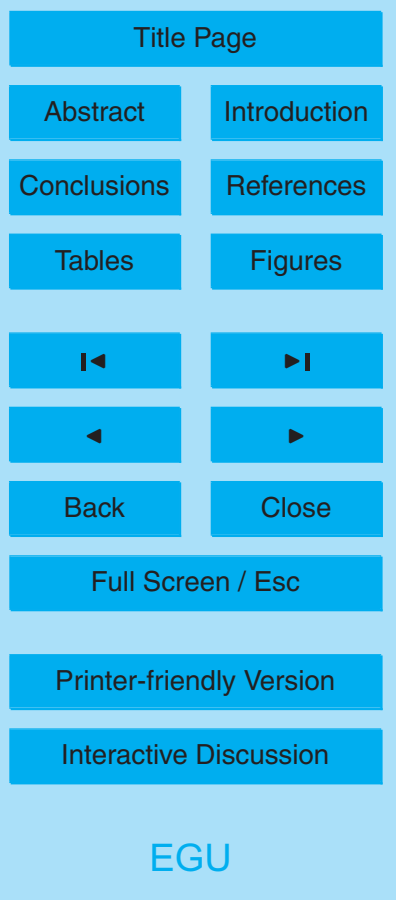


$3.1(-2.9,+3.5)$ pptv from VSLS.

The most abundant inorganic bromine species in the stratosphere during the daytime is BrO. Photochemical models have shown that it forms around $40-70 \%$ of $\mathrm{Br}_{\mathrm{y}}$ (e.g., Lary et al., 1996a; Sinnhuber et al., 2002). The primary source of BrO in the 5 stratosphere is the reaction

$\mathrm{Br}+\mathrm{O}_{3} \rightarrow \mathrm{BrO}+\mathrm{O}_{2}$

Other sources of $\mathrm{BrO}$ include photolysis of reservoir species like $\mathrm{BrONO}_{2}$ or reaction of $\mathrm{O}\left({ }^{3} \mathrm{P}\right)$ with reservoir species like $\mathrm{BrONO}_{2}$ (Soller et al., 2001; Sinnhuber et al., 2002, $2005)$ or $\mathrm{HOBr}$. The main sinks of $\mathrm{BrO}$ in the stratosphere are photolysis, reaction with ${ }_{10} \mathrm{O}\left({ }^{3} \mathrm{P}\right)$, and reaction with $\mathrm{NO}$. The reaction of $\mathrm{BrO}$ with $\mathrm{ClO}$ is also an important sink of $\mathrm{BrO}$ and also an important reaction for catalytic ozone destruction.

Among the reservoir bromine species, the most abundant species in the stratosphere during the daytime is $\mathrm{BrONO}_{2}$ which is formed by a three-body reaction

$\mathrm{BrO}+\mathrm{NO}_{2}+\mathrm{M} \rightarrow \mathrm{BrONO}_{2}+\mathrm{M}$

15 Photolysis of $\mathrm{BrONO}_{2}$ releases BrO back into the atmosphere. Thus, $\mathrm{BrONO}_{2}$ is very close to a photochemical steady state during the daytime. $\mathrm{BrONO}_{2}$ is believed to account for nearly half of $\mathrm{Br}_{\mathrm{y}}$ in the lower stratosphere during the daytime. The sink of $\mathrm{BrONO}_{2}$ during the daytime is photolysis or reaction of $\mathrm{O}\left({ }^{3} \mathrm{P}\right)$. The major nighttime loss of $\mathrm{BrONO}_{2}$ is through hydrolysis. Erle et al. (1998) have shown that hydrolysis of $\mathrm{BrONO}_{2}$ on cold stratospheric aerosols can be an important source of halogen activation. Also it influences $\mathrm{HO}_{\mathrm{x}}$ and $\mathrm{NO}_{\mathrm{x}}$ concentrations which has significant effect on ozone depletion (Lary, 1996b).

The hydrolysis of $\mathrm{BrONO}_{2}$ sulfate aerosols is also a source of $\mathrm{HOBr}$ (Lary et al., 1996a). Another important source of $\mathrm{HOBr}$ is the reaction of $\mathrm{BrO}$ with $\mathrm{HO}_{2}$. The 25 destruction of $\mathrm{HOBr}$ is through photolysis, which causes rapid increase of $\mathrm{HO}_{\mathrm{x}}$ during sunrise. $\mathrm{HOBr}$ is also destroyed through reaction with $\mathrm{O}\left({ }^{3} \mathrm{P}\right)$.

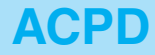

$6,6431-6466,2006$

\section{BrO from SCIAMACHY}

N. Sheode et al.

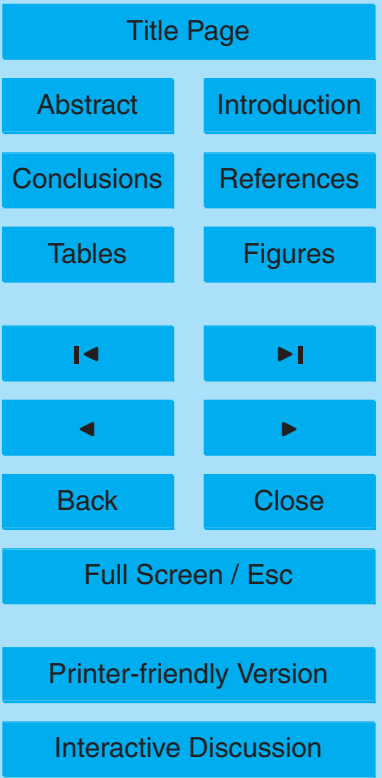


$\mathrm{HBr}$ is the longest lived reservoir species. $\mathrm{HBr}$ forms only a small fraction of $\mathrm{Br}_{y}$ in the stratosphere. The sources of $\mathrm{HBr}$ are the reaction of $\mathrm{Br}$ with $\mathrm{HO}_{2}$ and the reaction with formaldehyde (HCHO) (Lary et al., 1996a). A possible minor channel of source of $\mathrm{HBr}$ also exists through the reaction of $\mathrm{BrO}$ with $\mathrm{HO}_{2}$ (Lary et al., 1996a). Photochemical 5 models which included $0-2 \%$ production of $\mathrm{HBr}$ through the reaction of $\mathrm{BrO}$ with $\mathrm{HO}_{2}$ have been found to be in good agreement with field measurements (Johnson et al., 1995). The important sinks of $\mathrm{HBr}$ are reactions with $\mathrm{OH}$ and $\mathrm{O}\left({ }^{3} \mathrm{P}\right)$.

During the period of chlorine activation $\mathrm{BrCl}$ may become an important reservoir species through the reaction

$$
\mathrm{BrO}+\mathrm{ClO} \rightarrow \mathrm{BrCl}+\mathrm{O}_{2}
$$

In fact this is the smallest of the three channels which exists in the reaction of $\mathrm{BrO}$ and $\mathrm{CIO}$. The other two channels of the reaction of $\mathrm{BrO}$ and $\mathrm{ClO}$ result in the formation of (a) $\mathrm{OClO}+\mathrm{Br}$ (yield is $59 \%$ ) and (b) $\mathrm{ClOO}+\mathrm{Br}$ (yield is 34\%). The channel mentioned in Reaction (3) produces $7 \%$ yield of $\mathrm{BrCl}$ and $\mathrm{O}_{2}$. The yields mentioned are observed 15 at $195 \mathrm{~K}$ using JPL 2002 kinetics (Sander et al., 2003; Canty et al., 2005). During the daytime $\mathrm{BrCl}$ photolyses very quickly to produce $\mathrm{Br}$.

\section{SCIAMACHY BrO observations}

The SCIAMACHY instrument (Bovensmann et al., 1999) onboard ENVISAT was launched in March, 2002. ENVISAT flies in a sun synchronous low polar orbit with 20 equator crossing time of about $10 \mathrm{LT}$. SCIAMACHY measures sunlight transmitted through the Earth's atmosphere or reflected and scattered by the Earth's atmosphere and surface in the spectral range of $240-2380 \mathrm{~nm}$. The scattered and reflected spectral radiance is measured in nadir and limb geometry, while spectral radiance transmitted through the atmosphere is measured in solar or lunar occultation mode. The

\section{BrO from SCIAMACHY}

N. Sheode et al.

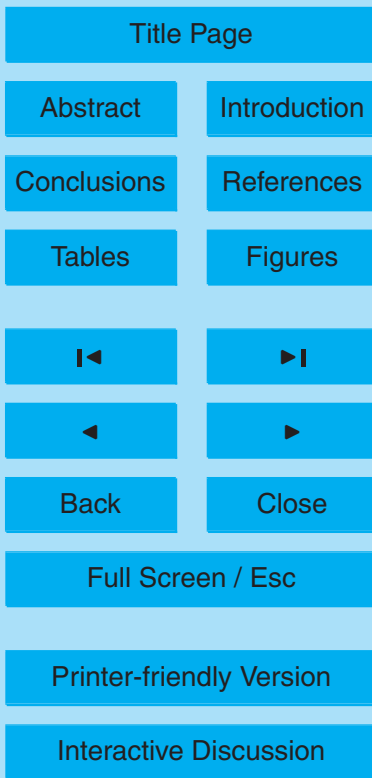


concentration of atmospheric trace gases. A detailed description of the instrument and its capabilities is given by Bovensmann et al. (1999).

$\mathrm{BrO}$ columns are retrieved from the nadir measurements, while the $\mathrm{BrO}$ profiles from the the limb measurements of SCIAMACHY. In this work the limb retrieval of $\mathrm{BrO}$ 5 (Rozanov et al., 2005a) are used.

\subsection{Retrieval of BrO profiles from SCIAMACHY limb observations}

Vertical distributions of $\mathrm{BrO}$ are retrieved from the SCIAMACHY limb measurements using the spectral information in the $337-357 \mathrm{~nm}$ wavelength interval. The forward simulations of the SCIAMACHY limb measurements as well as the calculations of the 10 appropriate weighting functions are done employing the SCIATRAN radiative transfer model (Rozanov, 2004; Rozanov et al., 2005b). In the spherical mode the SCIATRAN model calculates the limb radiance properly considering the single scattered radiance and using an approximation to account for the multiple scattering. To improve the retrieval quality, vertical profiles of $\mathrm{O}_{3}$ and $\mathrm{NO}_{2}$ are estimated in combination with $\mathrm{BrO}$ retrievals using the same spectral information. Limb measurements performed at tangent heights from 12 to $30 \mathrm{~km}$ are considered. To reduce the impact of the Fraunhofer structure and incorrect instrument calibration all selected limb scans are divided by the reference limb measurement obtained at a tangent height of about $33 \mathrm{~km}$. To account for broadband features resulting from unknown scattering properties of the atmosphere as well as instrument calibration issues, a cubic polynomial is subtracted from all spectral ratios and weighting functions.

The forward model is initialized using a climatological data base (C.A. McLinden, Personal communications), a background aerosol loading according to the LOWTRAN aerosol parameterization (Kneizys et al., 1996), a surface albedo of 0.3 , temperature dependent absorption cross sections of $\mathrm{O}_{3}, \mathrm{NO}_{2}$ and $\mathrm{BrO}$, and the $\mathrm{O}_{4}$ cross section from Greenblatt et al. (1990). The cross sections of $\mathrm{O}_{3}$ and $\mathrm{NO}_{2}$ were measured by the SCIAMACHY Proto Flight Model (PFM) Satellite Spectrometer (Bogumil et al., 1999) and the $\mathrm{BrO}$ cross sections were obtained by the time-resolved rapid scan Fourier

\section{BrO from SCIAMACHY}

N. Sheode et al.

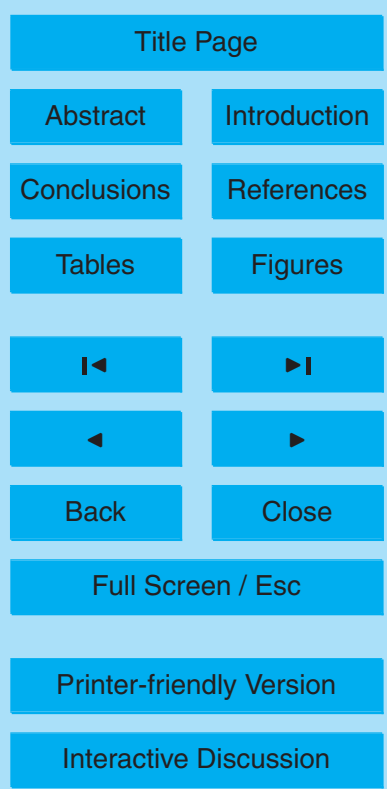


Transform Spectroscopy (FTS) method (Fleischmann et al., 2004) and then convolved to the SCIAMACHY resolution assuming the Gaussian form of the instrument slit function. The absorption cross section, which are used in the SCIAMACHY BrO limb retrievals have an accuracy of 10-20\% (Fleischmann et al., 2004).

5 The retrieval of $\mathrm{BrO}$ profiles is performed as described by Rozanov et al. (2005a) using a two-step retrieval procedure. At the preprocessing step, which is done for each tangent height independently, a possible misalignment of the wavelength grids of the limb spectra, of the reference spectrum, and of the forward model is accounted for. Additionally, known corrections, namely, the ring and tilt spectra, as well as instrument 10 calibration functions, are applied. The main retrieval step is based on the solution of the linearized forward equation given by

$y=K x+\epsilon$.

Here, the measurement vector, $\boldsymbol{y}$, contains the differences between ratios of simulated and measured differential limb spectra at all tangent heights selected for the 15 retrieval with all corrections from the preprocessing step applied, the state vector, $\boldsymbol{x}$, contains relative differences of trace gas number densities (with respect to the initial values) at all altitude layers for all gases to be retrieved, and $\epsilon$ denotes errors of any kind (e.g., measurement noise, linearization error, etc.). The linearized forward model operator, $K$ comprises of appropriate weighting functions. The final solution is 20 found iteratively employing the optimal estimation technique (Rodgers, 2000). Since no reliable statistical information on the vertical distribution of $\mathrm{BrO}$ is available, the Levenberg-Marquard iteration type (Dennis and Schnabel, 1983; Hanke, 1997) is employed replacing the a priori information at each iteration step by the results obtained at the previous iteration.

253.2 Sensitivity studies

In this section the dependence of the retrieved vertical profiles of $\mathrm{BrO}$ on the assumed atmospheric composition, surface reflection, and measurement geometry parameters

\section{BrO from SCIAMACHY}

N. Sheode et al.

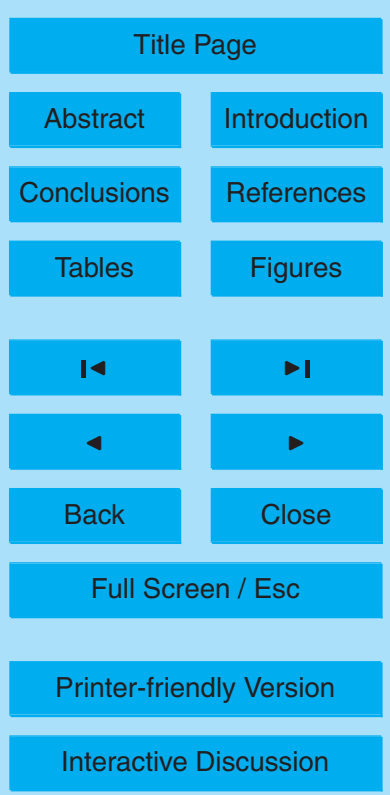


is investigated. This is done for a selected limb measurement performed on 3 July 2004 in the tropical region. The vertical profile of $\mathrm{BrO}$ obtained using the standard input for the forward model and the retrieval algorithm is treated as the reference. The vertical distributions retrieved using perturbed input parameters provide an estimate of 5 the sensitivity of the retrieval to the corresponding parameter.

The influence of atmospheric composition parameters such as pressure, temperature, and aerosol loading as well as of the surface reflection on the retrieved BrO mixing ratios is presented in Fig. 1. The reference vertical distribution of BrO obtained using the standard settings in the forward model and in the retrieval algorithm is shown by 10 the solid line. Other curves in the left panel in Fig. 1 depict the BrO volume mixing ratio profiles obtained for the perturbed input parameters. The shaded area represents the total estimated uncertainty of the retrieved profile. The right panel shows the relative differences of the corresponding profiles with respect to the reference (i.e., "unperturbed") profile. As seen from the plot, the largest influence on the retrieved $\mathrm{BrO}$ 15 profile is due to the change in the temperature profile. For example, a decrease in the temperature by $10 \mathrm{~K}$ results in a relative deviation in $\mathrm{BrO}$ mixing ratio of up to $60 \%$ in the lower stratosphere and up to $42 \%$ at higher altitude (shown by the dot-dashed line with pluses in the plot). However, it is worth mentioning that despite relatively high relative values, the absolute deviation in the retrieved $\mathrm{BrO}$ volume mixing ratio due to the change in the temperature profile by $10 \mathrm{~K}$ is always less than $0.5 \mathrm{pptv}$ below $23 \mathrm{~km}$. The dependence of the retrieved profiles on the temperature is most probably due to the temperature dependent cross sections, mostly of ozone, used in the forward model. The second largest influence on retrieved $\mathrm{BrO}$ profiles demonstrates the changes in the scattering properties of the atmosphere which may be caused by the changes in the pressure or aerosol loading. Thus, a decrease in pressure by $10 \%$ (dot-dot-dashed line with squares) and a reduction of scattering events in a pure Rayleigh atmosphere (dotdot-dot-dashed line with crosses) result in nearly the same relative deviations in the retrieved $\mathrm{BrO}$ profile of up to $20 \%$ whereas an increased stratospheric aerosol loading simulated using the moderate volcanic aerosol instead of background according to the

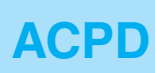

$6,6431-6466,2006$

\section{BrO from SCIAMACHY}

N. Sheode et al.

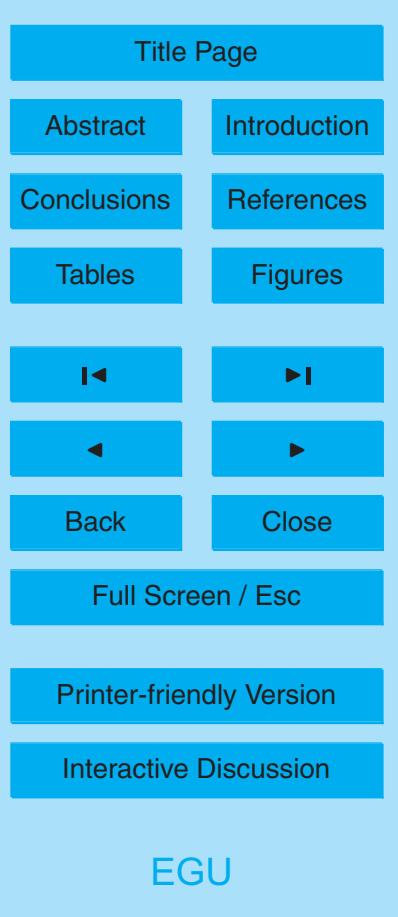


LOWTRAN aerosol parameterization (dashed line with diamonds) causes a relative deviation of nearly the same amount with an opposite sign. Illustrating a weak sensitivity of the employed method to the optical properties of the surface, the relative deviation in the retrieved $\mathrm{BrO}$ caused by the increase of the surface albedo to 0.9 remains always 5 below $10 \%$ (dotted line with triangles).

One of the main issues for all limb scattering instruments is the accuracy with which the tangent heights can be determined (von Savigny et al., 2004). Already in the early stage of the SCIAMACHY mission, a substantial error in the SCIAMACHY pointing as provided by ESA was identified. We studied the effect of wrong tangent height 10 alignment on the retrieval of the SCIAMACHY BrO.

Figure 2 illustrates the influence of the instrument mispointing on the retrieved $\mathrm{BrO}$ profiles. The presentation form here is similar to Fig. 1. The perturbed profiles are obtained associating the limb measurements to "wrong" values of the tangent height and then running the forward model and the retrieval. All tangent height values are 5 changed by the same amount simulating a constant shift in the tangent height alignment. Negative values for the tangent height shift denote that the assumed tangent height grid is shifted downwards with respect to the original one. Afterwards the retrieved $\mathrm{BrO}$ number density profiles are shifted back by the mispointing amount and converted into the volume mixing ratios. This is done to simulate the post-processing 20 pointing correction as it is applied to BrO profiles. As seen from the plot, the resulting error in $\mathrm{BrO}$ volume mixing ratio profiles due to $1 \mathrm{~km}$ mispointing is $10-20 \%$ above $21 \mathrm{~km}$ increasing to about $40 \%$ in the lower layers.

Figure 3 illustrates the influence of a priori information used in the forward model and in the retrieval algorithm on the retrieved $\mathrm{BrO}$ volume mixing ratio profiles. In the left 25 panel $\mathrm{BrO}$ volume mixing ratio retrieved assuming different a priori profiles is shown by curves with symbols. Corresponding a priori profiles are shown by the lines of the same type without symbols. Solid line depicts the standard retrieval. Due to decreasing information content of the limb measurements the largest impact of a priori information is expected in the lower stratosphere. Since the absolute values of $\mathrm{BrO}$ mixing ratio in

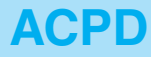

$6,6431-6466,2006$

\section{BrO from SCIAMACHY}

N. Sheode et al.

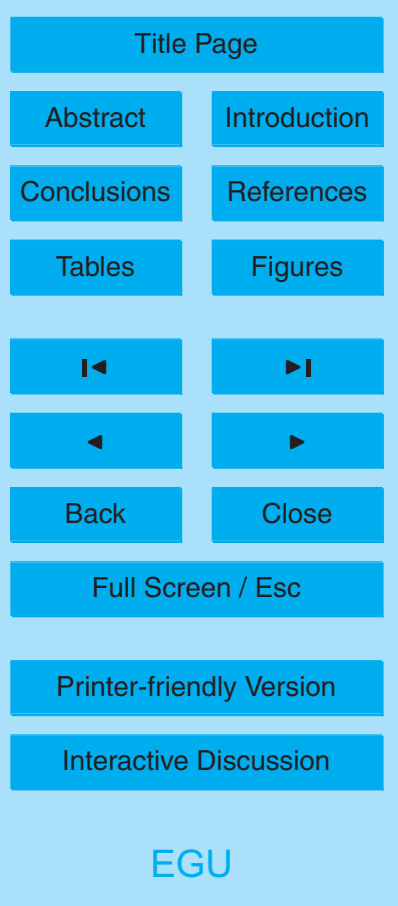


this altitude region are low, it is more convenient to show absolute differences in the $\mathrm{BrO}$ profile as presented in the right panel of Fig. 3. As seen from the plot, differences in $\mathrm{BrO}$ volume mixing ratio caused by the usage of different a priori profiles are typically within $0.6 \mathrm{pptv}$.

\section{3.3 Comparison with balloon-borne $\mathrm{BrO}$ profile measurements}

As a first step towards a validation of our SCIAMACHY BrO retrievals we compare our $\mathrm{BrO}$ profiles with the set of balloon-borne $\mathrm{BrO}$ measurements compiled by Dorf et al. (2005). Due to the diurnal variation of $\mathrm{BrO}$ it is necessary to include a photochemical correction of the measured $\mathrm{BrO}$ profiles that takes into account the differences in the time of day (and thus solar zenith angles) between the two measurements (for more details see Dorf et al., 2005). Forward and backward trajectories are started at the location of the balloon measurements and used to find optimal matches with SCIAMACHY profiles (Dorf et al., 2005). For two of the four balloon profiles forward and backward matches are available, for the other two only forward matches.

15 The relatively large statistical error of about $30 \%$ for individual SCIAMACHY $\mathrm{BrO}$ profiles makes it difficult to detect possible systematic differences when comparing individual profiles. Therefore we have also included the SCIAMACHY monthly mean $\mathrm{BrO}$ profiles for the corresponding latitude band in the comparison.

Figure 4 shows the comparison between the measured $\mathrm{BrO}$ profile from a TRIPLE 20 flight conducted on 24 September 2002 at Aire sur l'Adour, France $\left(44^{\circ} \mathrm{N}\right)$ with the SCIAMACHY BrO limb retrieval. As the TRIPLE flight was close in time to the SCIAMACHY overpass no photochemical correction was needed in this case. Figures 5 and 6 show the comparison with a DOAS flight on 23 March 2003 in Kiruna $\left(68^{\circ} \mathrm{N}\right)$ and with a DOAS flight on 9 October 2003 at Aire sur l'Adour. Figure 7 shows the comparison with a SAOZ flight at Bauru, Brazil $\left(22^{\circ} \mathrm{S}\right)$ on 31 January 2004 . For further information about the measurement techniques, photochemical correction of $\mathrm{BrO}$ profiles, and forward and backward trajectory mapping the reader is referred to Dorf et al. (2005).

The mean relative differences over the altitude range from 18 to $30 \mathrm{~km}$ are $+17 \%$

\section{BrO from SCIAMACHY}

N. Sheode et al.

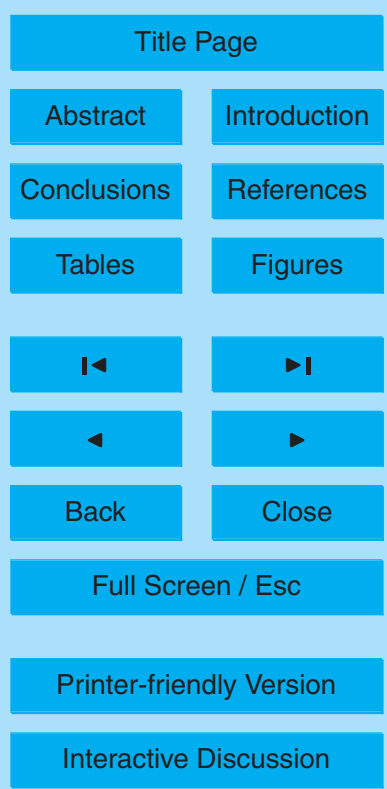


for the September 2002 TRIPLE flight at Aire sur l'Adour, $+14 \%$ for the March 2003 DOAS flight, $-20 \%$ and $-29 \%$ for the two matches of the October 2003 DOAS flight at Aire sur l'Adour, and $-32 \%$ and $-42 \%$ for the two matches of the January 2004 SAOZ flight at Bauru. Below $20 \mathrm{~km}$ our retrievals show very low amounts of $\mathrm{BrO}$ while the

$5 \mathrm{SAOZ}$ profile shows much higher BrO mixing ratios between 2 and 5 pptv. A comparison with first results from in-situ BrO measurements in the tropics (F. Stroh, personal communication, 2006) and the first DOAS BrO profile in the tropics (Dorf, 2005) show lower amounts of $\mathrm{BrO}$ below $20 \mathrm{~km}$ as compared to the SAOZ profile and appear to be in better agreement with our SCIAMACHY BrO retrievals. Although it is difficult to 10 be fully conclusive at this stage because of the large differences between the comparisons for the different balloon flights, the agreement between SCIAMACHY and the photochemically corrected balloon-borne $\mathrm{BrO}$ profiles is encouraging, in particular at mid-latitudes.

Dorf et al. (2005) have presented a comparison with SCIAMACHY BrO retrievals 15 performed with the Harvard Smithsonian algorithm (Sioris et al., 2006). The Harvard $\mathrm{BrO}$ retrievals seem to be systematically higher compared to our $\mathrm{BrO}$ retrievals, at least for the few profiles shown. The reason for this discrepancy is still unclear and will be investigated in an intercomparison project that was initiated recently.

\section{Photochemical modeling of the BrO diurnal variation}

\section{$20 \quad 4.1$ Model}

The 1-D model is based on the photochemical scheme from the SLIMCAT model (Chipperfield, 1999). The model contains a detailed stratospheric chemistry which includes gas phase as well as heterogeneous reactions. In all, there are 135 chemical reactions and 44 photolysis reactions of 52 species which are considered to be important for the stratospheric chemistry. The model is initialised with the output from a 2-D chemistry, transport and radiation model, which is a composite of the SLIMCAT chemistry (Chip-

\section{ACPD}

6, 6431-6466, 2006

\section{BrO from SCIAMACHY}

N. Sheode et al.

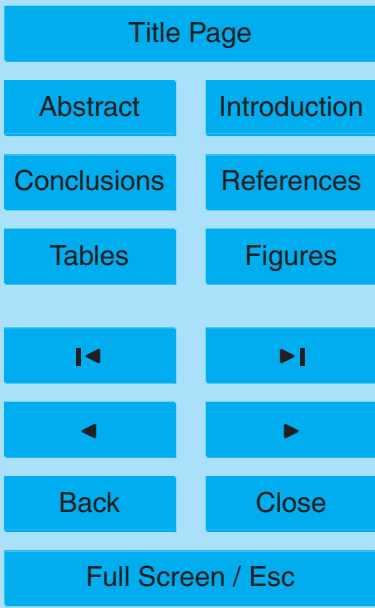

Printer-friendly Version

Interactive Discussion 
perfield, 1999; Sinnhuber et al., 2003) and the THIN AIR dynamics code (Kinnersley, 1996). Temperature and pressure in the model are taken from ECMWF analysis. The reaction rate constants and photolysis cross sections are taken from the latest JPL2002 recommendations (Sander et al., 2003). As mentioned previously the reaction of $5 \mathrm{BrONO}_{2}$ with $\mathrm{O}\left({ }^{3} \mathrm{P}\right)$ (Soller et al., 2001) could be an important source of $\mathrm{BrO}$ at higher altitudes (Sinnhuber et al., 2005). This reaction has not been considered in the JPL 2002 catalogue. However, we have included this reaction in our model simulations.

To estimate $\mathrm{Br}_{\mathrm{y}}$ in the stratosphere using the inorganic method, it is important to have a realistic partitioning of bromine species in the model. Since bromine partitioning is 10 controlled by $\mathrm{NO}_{2}$ (Fish et al., 1997; Richter et al., 1999), the 1-D model used in this study is constrained by the SCIAMACHY $\mathrm{NO}_{2}$ profiles by scaling $\mathrm{NO}, \mathrm{NO}_{2}, \mathrm{NO}_{3}$, and $\mathrm{HNO}_{3}$ (but not $\mathrm{ClONO}_{2}$ and BrONO2!) in the initialization until the modeled $\mathrm{NO}_{2}$ agrees with measured $\mathrm{NO}_{2}$ at the local time of the SCIAMACHY measurements. The model is run for a period of 5 days in order to allow for spin up and all calculations are done 15 using the output of the fifth day.

\subsection{Bromine partitioning}

Figure 8 shows the bromine partitioning for the four seasons and five latitude zones. In general it is observed that $\mathrm{BrO}$ and $\mathrm{BrONO}_{2}$ form a major part of the daytime $\mathrm{Br}_{\mathrm{y}}$. Other reservoir species like $\mathrm{HBr}, \mathrm{HOBr}, \mathrm{BrCl}$ form a very small fraction of $\mathrm{Br}_{\mathrm{y}}$. The model 20 calculations show that $\mathrm{BrO}$ is on an average $40-70 \%$ of $\mathrm{Br}_{\mathrm{y}}$, consistent with previous studies (Sinnhuber et al., 2002; Pundt et al., 2002). Avallone et al. (1995) compared model calculations of the $\mathrm{BrO} / \mathrm{Br}_{\mathrm{y}}$ ratio in the northern hemisphere lower stratosphere with in situ airborne observations. While their modeled $\mathrm{BrO} / \mathrm{Br}_{\mathrm{y}}$ ratio was around 50 $60 \%$, comparable to our results, the observations suggested a much smaller $\mathrm{BrO} / \mathrm{Br}_{\mathrm{y}}$ 25 ratio of only about $40 \%$. The reason for the discrepancy between their observed and modeled $\mathrm{BrO} / \mathrm{Br}_{\mathrm{y}}$ is still not clear.

During high-latitude winter (December-January-February in the Arctic and JuneJuly-August in the Antarctic) $\mathrm{BrO}$ is around $75 \%$ and $\mathrm{BrONO}_{2}$ forms only a small

\section{BrO from SCIAMACHY}

N. Sheode et al.

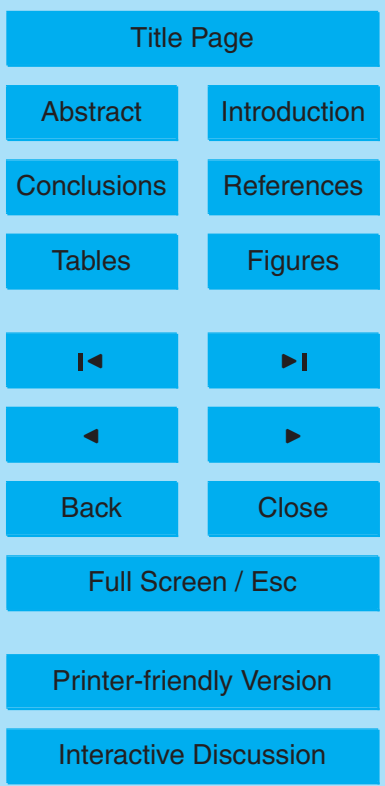


fraction of $\mathrm{Br}_{\mathrm{y}}$. This is due to the very low levels of $\mathrm{NO}_{\mathrm{x}}$ in this region and further demonstrates the role of $\mathrm{NO}_{x}$ in bromine partitioning. In the tropics, the partitioning of bromine species is similar to the other zones in the upper stratosphere. However in the lowermost stratosphere and in the uppermost troposphere, it is found that $\mathrm{HBr}$ 5 and $\mathrm{Br}$ form $10-40 \%$ of $\mathrm{Br}_{\mathrm{y}}$ while the concentration of $\mathrm{BrONO}_{2}$ is between $10-20 \%$ as against around $40 \%$ in the upper stratosphere. The reaction of $\mathrm{Br}$ with $\mathrm{HO}_{2}$ is a source of $\mathrm{HBr}$ while the reaction of $\mathrm{Br}$ with ozone is an important sink of $\mathrm{Br}$. The VMR of ozone is significantly low in the tropopause and the uppermost troposphere as compared to the stratospheric values. This results in $\mathrm{Br}$ and $\mathrm{HBr}$ forming a larger fraction of $10 \mathrm{Br}_{\mathrm{y}} . \mathrm{NO}_{2}$ does not appear to play a significant role in bromine partitioning in the lowermost stratosphere in the tropics. Antarctic winter is the only region where a significant amount of $\mathrm{BrCl}$ is predicted by the model. Under these conditions the model predicts also enhanced levels of $\mathrm{HOBr}$.

As these model calculations are constrained by $\mathrm{NO}_{2}$ from SCIAMACHY observa15 tions, the results depend to some extent on the accuracy of the SCIAMACHY $\mathrm{NO}_{2}$ observations. In order to check the effect of changes in $\mathrm{NO}_{2}$ on $\mathrm{BrO} / \mathrm{Br}_{\mathrm{y}}$ ratio, we conducted some sensitivity tests. An increase in $\mathrm{NO}_{2}$ concentration results in an increase in $\mathrm{BrONO}_{2}$ concentration through the Reaction (2). Consequently, this results in a decrease in $\mathrm{BrO}$. The change in $\mathrm{BrONO}_{2}$ and $\mathrm{BrO}$ is altitude dependent due to the pressure dependent nature of Reaction (2). On an average it is found that if we increase the $\mathrm{NO}_{2}$ concentration by $50 \%$ then $\mathrm{BrO}$ decreases by approximately $11 \%$ at altitudes of around $25 \mathrm{~km}$. Thus the $\mathrm{BrO} / \mathrm{Br}_{\mathrm{y}}$ ratio would decrease by $11 \%$. The statistical results from the comparison of all SCIAMACHY with Halogen Occultation Experiment instrument (HALOE) collocated $\mathrm{NO}_{2}$ profiles show a systematic negative offset of less than $5 \%$ between $20 \mathrm{~km}$ and $38 \mathrm{~km}$ (Bracher et al., 2004, ; A. Bracher, personal communication, 2005). This $5 \%$ bias in $\mathrm{NO}_{2}$ leads only to a bias in the calculated $\mathrm{BrO} / \mathrm{Br}_{\mathrm{y}}$ ratio of about $1 \%$ which is negligible compared to other potential error sources.

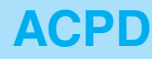

$6,6431-6466,2006$

\section{BrO from SCIAMACHY}

N. Sheode et al.

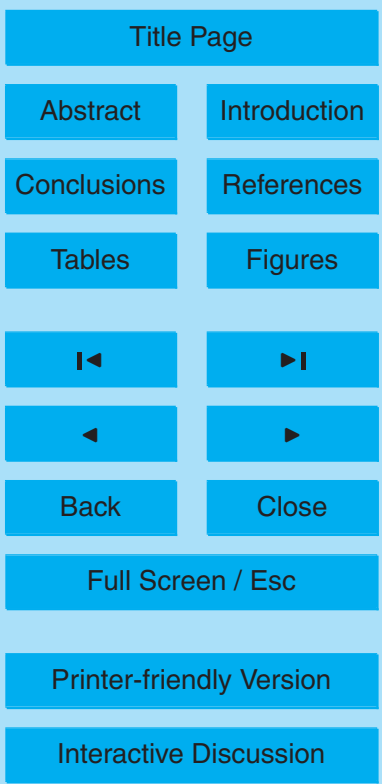




\section{BrO climatology and the seasonal variation of BrO}

A global seasonal climatology of stratospheric $\mathrm{BrO}$ is prepared from SCIAMACHY measurements during the years 2003 and 2004. However, data were not available for May, June, and July 2003 due to a change in the measurement mode of SCIAMACHY during 5 this period. This means that the climatology is based so far on observations from 21 months.

The area weighted monthly mean profiles are calculated over five latitude bands: The Arctic (north of $\left.60^{\circ} \mathrm{N}\right)$, northern hemisphere mid-latitudes $\left(30^{\circ} \mathrm{N}-60^{\circ} \mathrm{N}\right)$, tropics $\left(30^{\circ} \mathrm{S}-\right.$ $\left.30^{\circ} \mathrm{N}\right)$, southern hemisphere mid-latitudes $\left(30^{\circ} \mathrm{S}-60^{\circ} \mathrm{S}\right)$, and the Antarctic (south of $60^{\circ} \mathrm{S}$ ). Prior to this, the tangent height $(\mathrm{TH})$ corrections are applied to the monthly averaged profiles using the TH offsets given in Table 1 of von Savigny et al. (2005). Note that due to the inability of the instrument to measure in darkness, data are not available above $75^{\circ} \mathrm{N}$ in November, above $70^{\circ} \mathrm{N}$ in December and above $75^{\circ} \mathrm{N}$ in January. Similarly the data are not available above $70^{\circ} \mathrm{S}$ in May, above $65^{\circ} \mathrm{S}$ in June, and above

$1570^{\circ} \mathrm{S}$ in July. The seasonal averages are calculated according to the availability of the monthly zonal means. Temperature and pressure profiles needed to convert the $\mathrm{BrO}$ number densities to volume mixing ratios are taken from ECMWF.

On an average there are approximately 130 profiles per $5^{\circ}$ latitude bin per month. In calculating the seasonal zonal averages for two years, approximately 90000 profiles are used. The calculated seasonal means presented here, are interpolated to a common altitude grid for a better comparison.

Figure 9 shows the seasonal and zonal climatology of SCIAMACHY BrO between 15 and $28 \mathrm{~km}$. BrO VMRs increase with altitude at all latitudes mainly due to the dissociation of the organic bromine source species (Wamsley et al., 1998). During December25 January-February (DJF) in the northern hemisphere $(\mathrm{NH})$, BrO VMRs are larger at higher latitudes and altitudes as compared to the corresponding latitudes and altitudes in the southern hemisphere (SH). During March-April-May (MAM) BrO VMRs appear to be increasing at higher latitudes in the $\mathrm{SH}$ and during June-July-August (JJA) the

\section{BrO from SCIAMACHY}

N. Sheode et al.

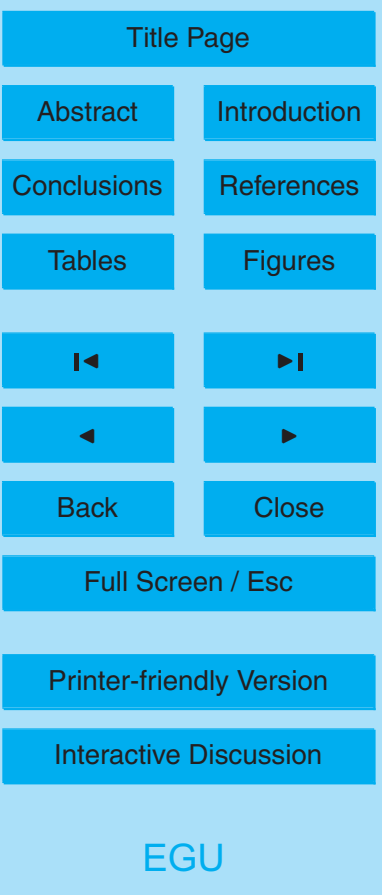


scenario is opposite to that during DJF. During September-October-November (SON) again the increase in BrO VMRs NH higher latitudes is observed.

The seasonal variation of $\mathrm{BrO}$ will in general be a result of changes in $\mathrm{Br}_{\mathrm{y}}$ due to transport and changes in the bromine partitioning due to chemistry. It is expected that 5 the $\mathrm{BrO} / \mathrm{Br}_{\mathrm{y}}$ ratio will show a seasonal variation anti-correlated to the seasonal cycle of $\mathrm{NO}_{2}$ : A rise in $\mathrm{NO}_{2}$ concentration will result in the rise in $\mathrm{BrONO}_{2}$ and consequently in the decrease in BrO (Fish et al., 1995). It is thus interesting to test, to what extent the observed seasonal variation of $\mathrm{BrO}$ can be explained by the seasonal cycle of $\mathrm{NO}_{2}$. Figures $10 \mathrm{a}, \mathrm{c}$, and e show the annual variation of $\mathrm{BrO}$ at $24 \mathrm{~km}$ in northern 10 mid-latitudes, the tropics and southern mid-latitudes, respectively for the year 2004. A strong annual variation of $\mathrm{BrO}$ at mid-latitudes of both hemispheres is evident, with a maximum in winter and a minimum in summer. The amplitude of the seasonal cycle of $\mathrm{BrO}$ at $24 \mathrm{~km}$ in the northern hemisphere is larger than in the southern hemisphere. Figures $10 \mathrm{~b}, \mathrm{~d}$ and $\mathrm{f}$ show that the annual variation of $\mathrm{BrO}$ is closely anti-correlated

with the $\mathrm{NO}_{2}$ concentrations, measured simultaneously by SCIAMACHY. The variation of $\mathrm{BrO}$ is qualitatively similar to the one addressed previously by Richter et al. (1999) over Bremen $\left(53^{\circ} \mathrm{N}\right)$. A comparison with the photochemical model shows that in the $\mathrm{NH}$ the change in $\mathrm{BrO}$ is larger than expected from changes in $\mathrm{NO}_{2}$ alone. This could mean that either other processes, in particular transport, contribute to the seasonal variation of $\mathrm{BrO}$ or current photochemistry underestimates the sensitivity of $\mathrm{BrO}$ to changes in $\mathrm{NO}_{2}$. However, since the $\mathrm{BrO}$ observations in the southern hemisphere do not show a higher sensitivity to changes in $\mathrm{NO}_{2}$ when compared to the model, this would argue against a chemical explanation and suggests that transport contributes to the observed $\mathrm{BrO}$ changes. Both $\mathrm{NO}_{2}$ and $\mathrm{BrO}$ show only little seasonal variation in 25 the tropical lower stratosphere.

Figure 11 shows the comparison of seasonally and zonally averaged profiles of $\mathrm{BrO}$ VMRs of the two years. DJF and SON are the only seasons where the seasonal and zonal mean BrO VMRs for the two years can be compared for all the latitude bands as the number of months used to calculate the seasonal average is same. The

\section{BrO from SCIAMACHY}

N. Sheode et al.

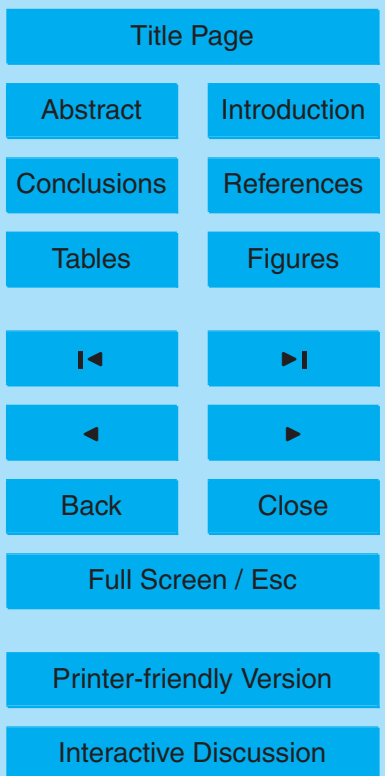

EGU

6446 
shapes of the $\mathrm{BrO}$ profiles for the same season and zone of the corresponding years (i.e. 2003 and 2004) are qualitatively consistent with each other. In general, we find that for all seasons and zones BrO VMR increases steadily with altitude and reaches peak values around $20-24 \mathrm{~km}$ and then remains constant between 9-14 pptv up to the

5 highest altitude. The averaged profiles are also qualitatively consistent with previously published work on $\mathrm{BrO}$ (Brune et al., 1989; Harder et al., 1998; Woyke et al., 1999; Toohey et al., 1990; Pundt et al., 2002).

In most cases, the seasonal mean BrO VMRs during 2003 are consistently larger than those during 2004. The tangent height offset applied during the two years may 10 contribute partly to this observed discrepancy. Also, a part of the larger discrepancy observed during MAM and JJA could be explained by the different number of months considered in calculating the seasonal averages in 2003 and 2004.

\section{Inferred $\mathrm{Br}_{\mathrm{y}}$ and the total bromine loading}

We have estimated $\mathrm{Br}_{\mathrm{y}}$ (by the so called inorganic method), using SCIAMACHY BrO 15 measurements and the calculated $\mathrm{BrO} / \mathrm{Br}_{\mathrm{y}}$ ratio from the photochemical model, constrained by the SCIAMACHY NO 2 observations. Figure 11 shows the profiles of $\mathrm{Br}_{\mathrm{y}}$ for the two years 2003 and 2004. The mean total stratospheric bromine loading $\left(\mathrm{Br}_{\text {total }}^{\text {mean }}\right)$ can be estimated by summing the calculated $\mathrm{Br}_{\mathrm{y}}$ and the estimate for the contribution of remaining organic bromine compounds. Based on CFC-11 observations in September 202002 from the Michelson Interferometer for Passive Atmospheric Sounding (MIPAS) also onboard ENVISAT (Glatthor et al., 2005) and the empirical relationship of Wamsley et al. (1998), we have estimated the average organic bromine in the extra-tropics to be $0.77 \mathrm{pptv}$ at $24 \mathrm{~km}$ and $0.15 \mathrm{pptv}$ at $27 \mathrm{~km}$ (see also Sinnhuber et al., 2005). The calculated extra-tropical $\mathrm{Br}_{\mathrm{y}}$ from SCIAMACHY $\mathrm{BrO}$ is on average $18.03 \mathrm{pptv}$ at $24 \mathrm{~km}$ and $2517.98 \mathrm{pptv}$ at $27 \mathrm{~km}$. Using the average organic bromine at 24 and $27 \mathrm{~km}$ for September 2002 (as representative of the whole year to a first approximation) and the average value of estimated $\mathrm{Br}_{\mathrm{y}}$ at the same altitudes, the mean total bromine loading in the

\section{BrO from SCIAMACHY}

N. Sheode et al.

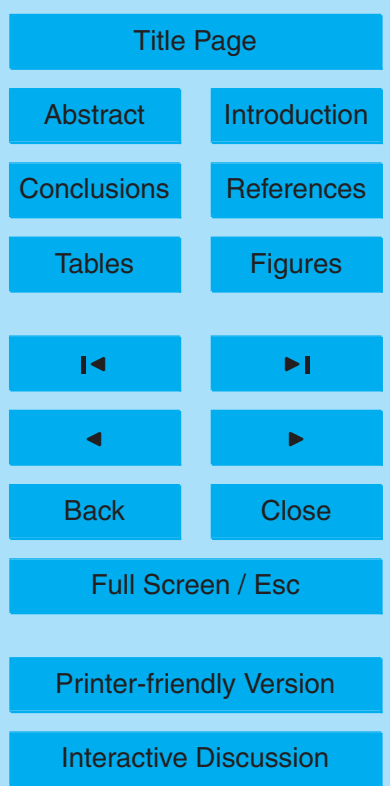


stratosphere around $25 \mathrm{~km}\left(\mathrm{Br}_{\text {total }}^{\text {mean }}\right)$ is found to be $18.5 \mathrm{pptv}$. Assuming an accuracy of about $20 \%$ for the SCIAMACHY BrO profile retrievals the uncertainty in $\mathrm{Br}_{\text {total }}^{\text {mean }}$ will be about \pm 3.7 pptv.

This estimate of $\mathrm{Br}_{\text {total }}^{\text {mean }}$ is consistent (albeit with higher uncertainty) with the works 5 of Schauffler et al. (1998), who calculated the total organic bromine loading at the tropical tropopause to be $17.4 \pm 0.9$ using the organic method which included 3 short lived species namely $\mathrm{CH}_{2} \mathrm{Br}_{2}, \mathrm{CH}_{2} \mathrm{BrCl}$, and $\mathrm{CHCl}_{2} \mathrm{Br}$ apart from $\mathrm{CH}_{3} \mathrm{Br}$ and halons. The calculated value is also consistent with works of Wamsley et al. (1998) (which ranged from (16.4 \pm 2 pptv) in 6 year old air investigated in 1994 to $(18.2 \pm 2)$ in 0 year old air) using organic method which included $\mathrm{CH}_{3} \mathrm{Br}$, halons and two short lived species namely $\mathrm{CH}_{2} \mathrm{Br}_{2}$ and $\mathrm{CH}_{2} \mathrm{BrCl}$ and that of Pfeilsticker et al. (2000) who estimated for early 1999, the total organic bromine at $25 \mathrm{~km}$ in air of 5.6 year mean age to be 18.4 $(+1.8 /-1.5)$ pptv from organic precursor measurements which included all known major organic bromine species.

15 However, the estimated value of total bromine loading in this work is on the lower side (though within stated error of measurements) as compared to previous works which calculated the total bromine loading using $\mathrm{BrO}$ measurements and known $\mathrm{BrO} / \mathrm{Br}_{\mathrm{y}}$ from the model e.g. the work of Pfeilsticker et al. (2000) who estimated inorganic bromine loading of $21.5 \pm 3$ pptv for air of 5.6 year mean age for winter 1998/99, Harder et al.

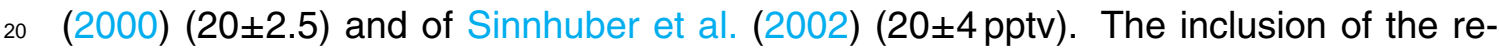
action proposed by Soller et al. (2001) decreases the gap between between this work and that of Pfeilsticker et al. (2000), Harder et al. (2000).

The major contribution to the bromine in the stratosphere is from $\mathrm{CH}_{3} \mathrm{Br}$, Halon-1211 and Halon-1301 (Wamsley et al., 1998; Pfeilsticker et al., 2000) and this sums up to 2515 pptv (Sinnhuber et al., 2005). The total bromine loading of $18.5 \pm 4$ pptv estimated in this work indicates a contribution of $3.5 \pm 4$ pptv from short lived to stratospheric bromine loading in addition to that from $\mathrm{CH}_{3} \mathrm{Br}$ and halons in agreement with previous studies (Pfeilsticker et al., 2000; Sinnhuber et al., 2002, 2005; Salawitch et al., 2005).

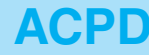

$6,6431-6466,2006$

\section{BrO from SCIAMACHY}

N. Sheode et al.

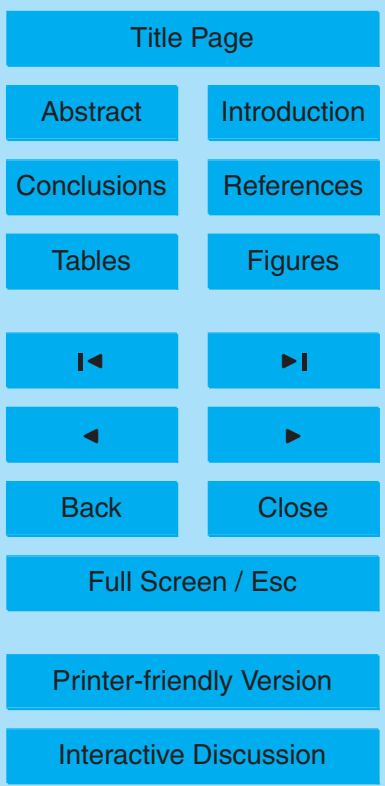




\section{Conclusions}

We present a first global climatology of stratospheric $\mathrm{BrO}$, based on retrievals from two years of measurements of the SCIAMACHY satellite instrument. A comparison of the SCIAMACHY BrO retrievals with a set of balloon-borne $\mathrm{BrO}$ measurements shows 5 mean differences in the altitude region from 18 to $30 \mathrm{~km}$ between $+17 \%$ and $-29 \%$ at mid and high latitudes of the northern hemisphere. Larger discrepancies of $-32 \%$ and $-42 \%$ are found in comparison to a SAOZ balloon profile in the tropics.

$\mathrm{BrO}$ shows a strong annual variation at mid-latitudes while there is no significant annual variation in the tropics. The seasonal variation at mid-latitudes is inversely correlated with $\mathrm{NO}_{2}$, confirming our present understanding of the gas phase bromine chemistry.

The total bromine loading is estimated from the $\mathrm{BrO}$ observations using the inorganic method. The total bromine loading is $18.5 \pm 4$ pptv consistent with previously published results (Schauffler et al., 1998; Wamsley et al., 1998; Pfeilsticker et al., 2000; Harder et al., 2000; Sinnhuber et al., 2002; WMO, 2002). Our estimate is slightly on the lower side (though within the stated error estimates) as compared to the estimates of (Pfeilsticker et al., 2000; Harder et al., 2000). Part of the difference can be explained by the inclusion of the reaction of $\mathrm{BrONO}_{2}$ with $\mathrm{O}\left({ }^{3} \mathrm{P}\right)$ (Soller et al., 2001). The total bromine loading of $18.5 \pm 4$ pptv suggests a contribution of $3.5 \pm 4$ pptv from short lived organic bromine compounds in addition to methyl bromide and the halons.

Acknowledgements. This work was supported by the German Ministry of Education and Research BMBF, the German Aerospace Center DLR, and the EU projects TOPOZ-III, THALOZ, and SCOUT-O3 and PEP. Part of the retrieval calculations were performed at High-Performance Computer Center North (HLRN). Services and support are gratefully acknowledged. We acknowledge the access to meteorological analysis through the ECMWF Special Project SPDECDIO. We thank M. Dorf and the IUP/Heidelberg team for providing the balloon-borne BrO profiles.

\section{BrO from SCIAMACHY}

N. Sheode et al.

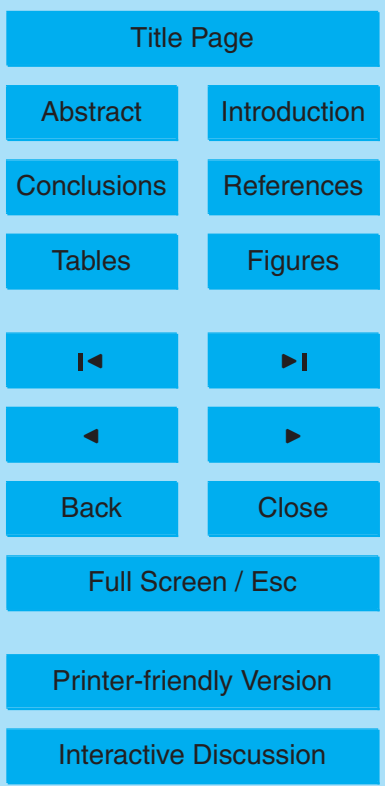




\section{References}

Afe, O. T., Richter, A., Sierk, B., Wittrock, F., and Burrows, J. P.: BrO emissions from volcanoes: A survey using GOME and SCIAMACHY measurements, Geophys. Res. Lett., 31, L24113, doi:10.1029/2004GL020994, 2004. 6434

5 Avallone, L. M., Toohey, D. W., Schauffler, S. M., Pollock, W. H., Heidt, L. E., Atlas, E. L., and Chan, K. R.: In-situ measurements of BrO during AASE-II, Geophys. Res. Lett., 22, 831-834, 1995. 6433, 6443

Bobrowski, N., Hönninger, G., Galle, B., and Platt, U.: Detection of bromine monoxide in a volcanic plume, Nature, 423, 273-276, 2003. 6434

10 Bogumil, K., Orphal, J., Voigt, S., Bovensmann, H., Fleischmann, O. C., Hartmann, M., Homann, T., Spietz, P., Vogel, A., and Burrows, J. P.: Reference Spectra of Atmospheric Trace Gases Measured by the SCIAMACHY PFM Satellite Spectrometer, 2, 443-447, proc. 1st Europ. Sympos. Atmos. Meas. from Space (ESAMS-99), ISSN 1022-6656, ESA-ESTEC, Noordwicjk, 1999. 6437

15 Bovensmann, H., Burrows, J. P., Buchwitz, M., Frerick, J., Noël, S., and Rozanov, V. V.: SCIAMACHY: Mission objectives and measurement modes, J. Atmos. Sci., 56, 127-149, 1999. 6436, 6437

Bracher, A., Sinnhuber, M., Rozanov, A., and Burrows, J. P.: Using photochemical model for the validation of $\mathrm{NO}_{2}$ satellite measurements at different solar zenith angles, At-

20 mos. Chem. Phys., 5, 393-408, 2005. 6444

Brune, W. H., Anderson, J. G., and Chan, K. R.: In-situ observations of BrO over Antarctica:ER2 aircraft results from 54 S to 72 S, J. Geophys. Res., 94, 16 639, 1989. 6433, 6447

Canty, T., Rivière, E. D., Salawitch, R. J., Berthet, G., Renard, J.-B., Pfeilsticker, K., Dorf, M., Butz, A., Bösch, H., Stimpfle, R. M., Wilmouth, D. M., Richard, E. C., Fahey, D. W., Popp, P. J., Schoeberl, M. R., Lait, L. R., and Bui, T. P.: Nighttime OClO in the Arctic vortex, J. Geophys. Res., 110, D01301, doi:10.1029/2004JD005035, 2005. 6436

Carroll, M. A., Sanders, R. W., Solomon, S., and Schmeltekopf, A. L.: Visible and nearultraviolet spectroscopy at McMurdo station, Antarctica, 6, Observations of BrO, J. Geophys. Res., 94, 16633, 1989. 6433

30 Chipperfield, M.: Multiannual simulations with a three dimensional chemical transport model, J. Geophys. Res., 104, 1781-2805, 1999. 6442

Dennis, J. E. and Schnabel, R. B. (Eds.): Numerical Methods for Unconstrained Optimization

\section{BrO from SCIAMACHY}

N. Sheode et al.

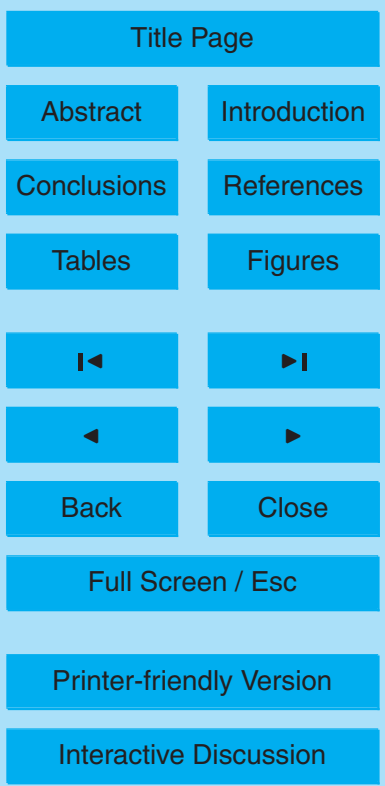


and Nonlinear Equations, Prentice Hall, 1983. 6438

Dorf, M.: Investigation of inorganic stratospheric bromine using balloon-borne DOAS measurements amd model simulations, Ph.D. Thesis, Univ. of Heidelberg, Germany, 2005. 6442

Dorf, M., Bösch, H., Butz, A., Camey-Peyret, C., Chipperfield, M. P., Engel, A., Goutail, F., Grunov, K., Hendrick, F., Hrechanyy, S., Naujokat, B., Pommereau, J. P., Roozendael, M. V., Sioris, C., Stroh, F., Weidner, F., and Pfeilsticker, K.: Balloon-borne stratospheric BrO measurements: Comparison with Envisat/SCIAMACHY BrO limb profiles, Atmos. Chem. Phys. Discuss., 5, 13011-13052, 2005. 6433, 6441, 6442

Dvortsov, V. L., Geller, M. A., and Solomon, S., Schauffler, S. M., Atlas, E. L., and Blake, D. R.: Rethinking reactive halogen budgets in the mid-latitude lower stratosphere, Geophys. Res. Lett., 26, 1699-1702, 1999. 6434

Erle, F., Grendel, A., Perner, D., Platt, U., and Pfeilsticker, K.: Evidence of heterogeneous bromine chemistry on cold stratospheric sulphate aerosols, Geophys. Res. Lett., 25, 43294332, 1998. 6435

15 Fish, D. J., Jones, R. L., and Strong, E. K.: Mid-latitude observations of the diurnal variation of stratospheric BrO, J. Geophys. Res., 100, 18863-18 871, 1995. 6446

Fish, D. J., Aliwell, S. R., and Jones, R. L.: Mid-latitude observations of the seasonal variation of $\mathrm{BrO}, 2$, Interpretation and modelling study, Geophys. Res. Lett., 24, 1199-1202, 1997. 6433, 6443

20

Fleischmann, O. C., Hartmann, M., Burrows, J. P., and Orphal, J.: New ultraviolet absorption cross-sections of $\mathrm{BrO}$ at atmospheric temperatures measured by time-windowing Fourier transform spectroscopy, J. Photochem. Photobio., A: Chemistry, 168, 117-132, 2004. 6438

Frieß, U., Chipperfield, M. P., Harder, H., Otten, C., Platt, U., Pyle, J., Wagner, T., and Pfeilsticker, P.: Intercomparison of measured and modelled $\mathrm{BrO}$ slant column amounts for the arctic winter and spring 1994/1995, Geophys. Res. Lett., 26, 1861-1864, 1999. 6433

Glatthor, N., von Clarmann, T., Fischer, H., et al.: Mixing processes during the Antarctic vortex split in September and October 2002 as inferred from source gas and ozone from MIPAS/ENVISAT, J. Atmos. Sci., 62, 787-800, 2005. 6447

Greenblatt, G. D., Orlando, J. J., Burkholder, J. B., and Ravishankara, A. R.: Absorption measurements of oxygen between 330 and 1140 nm, J. Geophys. Res., 95, 18 577-18582, 1990. 6437

Hanke, M. (Ed.): A regularizing Levenberg-Marquardt scheme, with applications to inverse groundwater filtration problems, Inverse Problems, 13, 79-95, 1997. 6438
ACPD

6, 6431-6466, 2006

\section{BrO from \\ SCIAMACHY}

N. Sheode et al.

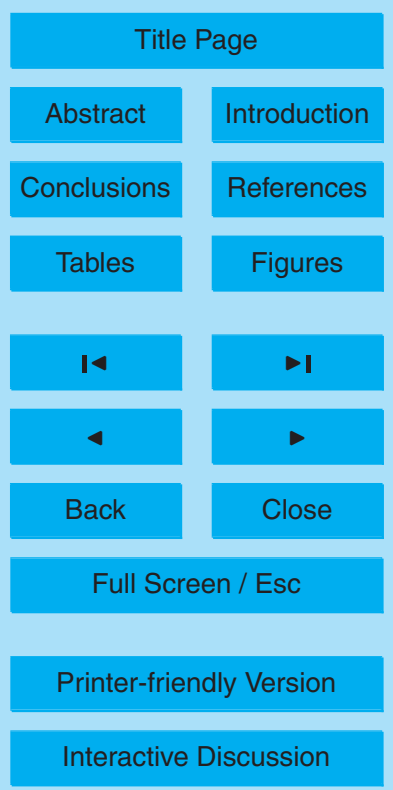


Harder, H., Camy-Peyret, C., Ferlemann, F., Fitzenberger, R., Hawat, T., Osterkamp, H., Schneider, M., Perner, D., Platt, U., Vradelis, P., and Pfeilsticker, K.: Stratospheric BrO profiles measured at different latitudes and seasons: Atmospheric observations, Geophys. Res. Lett., 25, 3843-3846, 1998. 6433, 6447

5 Harder, H., Bösch, H., Camy-Peyret, C., Chipperfield, M. P., Fitzenberger, R., Payan, S., Perner, D., Platt, U., Sinnhuber, B.-M., and Pfeilsticker, K.: Comparison of measured and modeled BrO:Implications for the total amount of stratospheric BrO, Geophys. Res. Lett., 27, 36953698, 2000. 6434, 6448, 6449

Johnson, D. G., Traub, W. A., Chance, K. V., and Jucks, K. W.: Detection of $\mathrm{HBr}$ and upper limit of HOBr: Bromine partitioning in the stratosphere, Geophys. Res. Lett., 22, 1373-1376, 1995. 6432, 6436

Kinnersley, J. S.: The meteorology of the stratosphere THIN AIR model, Q. J. R. Meteorol. Soc., 122, 219-252, 1996. 6443

Kneizys, F., Abreu, L., Anderson, G., Chetwynd, J., Shettle, E., Berk, A., Bernstein, L., Robertson, D., Acharya, P., Rothman, L., Selby, J., Gallery, W., and Cough, S.: The MODTRAN 2/3 report and LOWTRAN 7 model, Phillips Laboratory, Hanscom AFB, tech. Rep., contract F19628-91-C-0132 with Ontar Corp., 1996. 6437

Lary, D. J.: Gas phase atmospheric bromine photochemistry, J. Geophys. Res., 101, 15051516, 1996b. 6435

20 Lary, D. J., Chipperfield, M. P., Toumi, R., and Lenton, T.: Heterogeneous atmospheric bromine chemistry, J. Geophys. Res., 101, 1489-1504, 1996a. 6435, 6436

McKinney, K. A., Pierson, J. M., and Toohey, D. W.: A wintertime in situ profile of BrO between 17 and $27 \mathrm{~km}$ in the Arctic vortex, Geophys. Res. Lett., 24, 853-856, 1997. 6433

Nielsen, J. E. and Douglass, A. R.: A simulation of bromoform's contribution to stratospheric bromine, J. Geophys. Res., 106, 8089-8100, 2001. 6434

Nolt, I. G.: Stratospheric $\mathrm{HBr}$ concentration profile obtained from far-infrared emission spectroscopy, Geophys. Res. Lett., 24, 281-284, 1997. 6432

Otten, C., Ferlemann, F., Platt, U., Wagner, T., and Pfeilsticker, K.: Ground based DOAS UV/visible measurements at Kiruna (Sweden) during SESAME winters 1993/94 and 1994/95, J. Atmos. Chem., 30, 141-162, 1998. 6433

Pfeilsticker, K., Sturges, W. T., Bösch, H., Camy-Peyret, C., Chipperfieled, M. P., Engel, A., Fitzenberger, R., Müller, M., Payan, S., and Sinnhuber, B.-M.: Lower stratospheric organic and inorganic bromine budget for the arctic winter 1998/99, Geophys. Res. Lett., 27, 3305-

\section{BrO from SCIAMACHY}

N. Sheode et al.

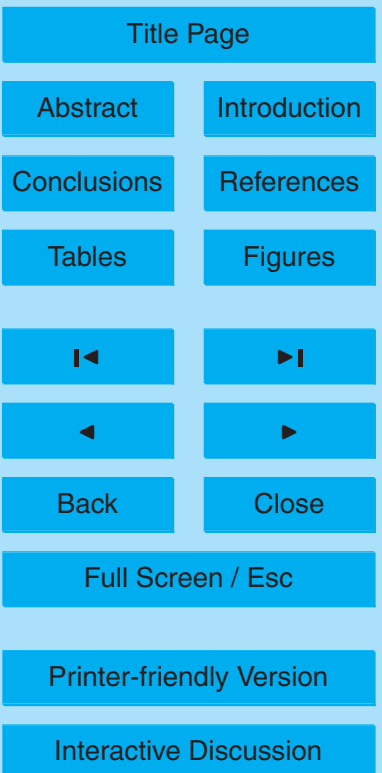


3308, 2000. 6434, 6448, 6449

Pundt, I., Pommereau, J. P., Chipperfield, M. P., Roozendael, M. V., and Goutail, F.: Climatology of stratospheric $\mathrm{BrO}$ vertical distribution by balloon-borne UV-visible spectrometry, J. Geophys. Res., 107, 4806, doi:10.1029/2002JD002230, 2002. 6433, 6443, 6447

5 Richter, A., Esinger, M., Ladstätter-Weissenmayer, A., and Burrows, J. P.: DOAS zenith sky observations, 2, Seasonal variation of BrO over Bremen (53 N 1994-1995), J. Atmos. Chem., 32, 83-99, 1999. 6433, 6443, 6446

Richter, A., Wittrock, F., Ladstätter-Weissenmayer, A., and Burrows, J. P.: GOME measurements of stratospheric and tropospheric BrO, Adv. Space Res., 29, 1667-1672, 2002. 6433

Rodgers, C. D. (Ed.): Inverse Methods for Atmospheric Sounding: Theory and Practice, World Scientific, Singapore, New Jersey, London, Hongkong, 2000. 6438

Rozanov, A.: http://www.iup.physik.uni-bremen.de/sciatran, 2004. 6437

Rozanov, A., Bovensmann, H., Bracher, A., Hrechanyy, S., Rozanov, V., Sinnhuber, M., Stroh, F., and Burrows, J. P.: $\mathrm{NO}_{2}$ and $\mathrm{BrO}$ vertical profile retrieval from SCIAMACHY limb measurements: Sensitivity studies, Adv. Space. Res., 36, 846-854, 2005a. 6437, 6438

Rozanov, A., Rozanov, V., Buchwitz, M., Kokhanovsky, A., and Burrows, J. P.: SCIATRAN 2.0 - A new radiative transfer model for geophysical applications in the $175-2400 \mathrm{~nm}$ spectral region, Adv. Space. Res., 36, 11015-1019, 2005b. 6437

Salawitch, R. J., Weisentein, D. K., Kovalenko, L. J., Sioris, C. E., Wennberg, P. O., Chance, K., Ko, M. K. O., and Mclinden, C. A.: Sensitivity of ozone to bromine in the lower stratosphere, Geophys. Res. Lett., 32, L05811, doi:10.1029/2004GL021504, 2005. 6448

Sander, S. P., Friedl, R. R., Golden, D. M., Kurylo, M. J., Huie, R. E., Orkin, V. L., Moortgat, G. K., Ravishankara, A. R., Kolb, C. E., Molina, M. J., and Finlayson-Pitts, B. J.: Chemical kinetics and photochemical data for use in atmospheric studies, Jet Propulsion Laboratory, 2003. 6436,6443

Schauffler, S. M., Atlas, E. L., Flocke, F., Lueb, R. A., Stroud, V., and Travnicek, W.: Measurements of bromine containing organic compounds at the tropical tropopause, Geophys. Res. Lett., 25, 317-320, 1998. 6434, 6448, 6449

Schofield, R., Kreher, K., Connor, B. J., Johnston, P. V., Thomas, A., Shooter, D., Chipperfield, M. P., Rodgers, C. D., and Mount, G. H.: Retrieved tropospheric and stratospheric BrO columns over Lauder, New Zealand, J. Geophys. Res., 109, D14304, doi:10.1029/2003JD004463, 2004. 6433

Sinnhuber, B.-M. and Folkins, I.: Estimating the contribution of bromoform to strato-

\section{BrO from SCIAMACHY}

N. Sheode et al.

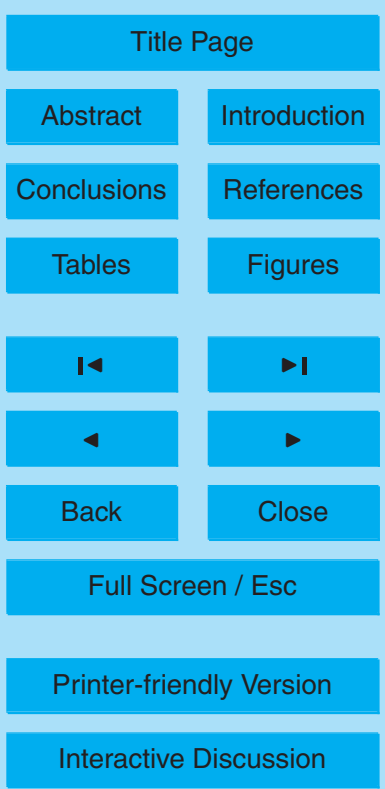


spheric bromine and its relation to dehydration in the tropical tropopause layer, Atmos. Chem. Phys. Discuss., 5, 12939-12 956, 2005. 6434

Sinnhuber, B.-M., Arlander, D. W., Bovensmann, H., Burrows, J. P., Enell, M. P. C. C.-F., Frieß, U., Hendrick, F., Johnston, P. V., Jones, R. L., Kreher, K., Mohamed-Tahrin, N., Müler, R., $5 \quad$ Pfeilsticker, K., Platt, U., Pommereau, J. P., Pundt, I., Richter, A., South, A. M., Tøornkvist, K. K., Roozendael, M. V., Wagner, T., and Wittrock, F.: Comparison of measurements and model calculations of stratospheric bromine monoxide, J. Geophys. Res., 107, 4398, doi:10.1029/2001JD000940, 2002. 6433, 6434, 6435, 6443, 6448, 6449

Sinnhuber, B.-M., Rozanov, A., Sheode, N., Afe, O. T., Richter, A., Sinnhuber, M., Wittrock, F., Burrows, J. P., P.Stiller, G., von Clarmann, T., and Linden, A.: Global observations of stratospheric bromine monoxide from SCIAMACHY, Geophys. Res. Lett., 32, L20810, doi:10.1029/2005GL023839, 2005. 6433, 6434, 6435, 6443, 6447, 6448

Sinnhuber, M., Burrows, J. P., Chipperfield, M. P., Jackman, C. H., Kallenrode, M. B., Künzi, K., and Quack, M.: A model study of the impact of magnetic field structure on atmospheric composition during solar proton event, Geophys. Res. Lett., 1818, doi:10.1029/2003GL017265, 2003. 6443

Sioris, C. E., Kovalenko, L. J., Mclinden, C. A., Salawitch, R. J., Roozendael, M. V., Goutail, F., Dorf, M., Pfeilsticker, K., Chance, K., Liu, X., Kuroso, T. P., Pommereau, J.-P., Bösch, H., and Frerick, J.: Latitudinal and vertical distribution of bromine monoxide in the lower stratosphere from SCIAMACHY limb scattering measurements, J. Geophys. Res., in press, 2006. 6442

Soller, R., Nicovich, J. M., and Wine, P. H.: Temperature-dependent rate coefficients for the reactions of $\mathrm{Br}\left({ }^{2} \mathrm{P}_{3 / 2}\right), \mathrm{Cl}\left({ }^{2} \mathrm{P}_{3 / 2}\right), \mathrm{O}\left({ }^{3} \mathrm{P}_{j}\right)$ with $\mathrm{BrONO}_{2}$, J. Phys. Chem., 105, 1416-1422, 2001. 6435, 6443, 6448, 6449

Solomon, S., Sanders, R. W., Carroll, M. A., and Schmeltekopf, A. L.: Visible and nearultraviolet spectroscopy at McMurdo station, Antarctica, 5, Observations of the diurnal variation of BrO and OCIO, J. Geophys. Res., 94, 11 393-11403, 1989. 6433

Sturges, W. T., Oram, D. E., Carpenter, L. J., Penkett, S. A., and Engel, A.: Bromoform as a source of stratospheric bromine, Geophys. Res. Lett., 27, 2081-2084, 2000. 6434

Toohey, D. W., Anderson, J. G., Brune, W. H., and Chan, K. R.: In-situ measurements of BrO in the arctic stratosphere, Geophys. Res. Lett., 17, 513, 1990. 6433, 6447

von Savigny, C., Eichmann, K.-U., Bovensmann, H., and Burrows, J. P.: Report on the 1st international workshop on limb scattering, SPARC Newsletter, 22, 2004. 6440

von Savigny, C., Kaiser, J. W., Bovensmann, H., Burrows, J. P., McDermid, I. S., and Leblanc,

\section{BrO from SCIAMACHY}

N. Sheode et al.

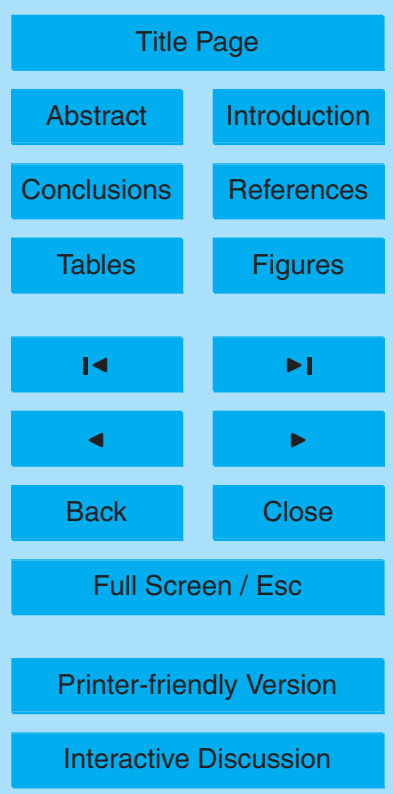

EGU 
T.: Spatial and temporal characterization of SCIAMACHY limb pointing errors during the first three years of the mission, Atmos. Chem. Phys., 5, 2593-2602, 2005. 6445

Wagner, T. and Platt, U.: Satellite mapping of enhanced BrO concentrations in the troposphere, Nature, 395, 486-490, 1998. 6433

5 Wamsley, P. R., Elkins, J. W., Fahey, D. W., Dutton, G. S., Volk, C. M., Myers, R. C., Montzka, S. A., Butler, J. H., Clarke, A. D., Fraser, P. J., and Steele, L. P.: Distribution of halon1211 in the upper troposphere and lower stratosphere and the 1994 total bromine budget, J. Geophys. Res., 103, 1513-1526, 1998. 6434, 6445, 6447, 6448, 6449

WMO: Scientific assesment of ozone depletion: 2002. WMO, Global ozone research and monitoring project: Report no. 47, 2002. 6449

Woyke, T., Müller, R., Stroh, F., McKenna, D. S., Engel, A., Margitan, J. J., Rex, M., and Carslaw, K. S.: A test of our understanding of the ozone chemistry in the arctic polar vortex based on in situ measurements of $\mathrm{ClO}, \mathrm{BrO}$ and $\mathrm{O}_{3}$ in the 1994/1995 winter, J. Geophys. Res., 104, 18755-18768, 1999. 6447

\section{ACPD}

$6,6431-6466,2006$

\section{BrO from SCIAMACHY}

N. Sheode et al.

Title Page

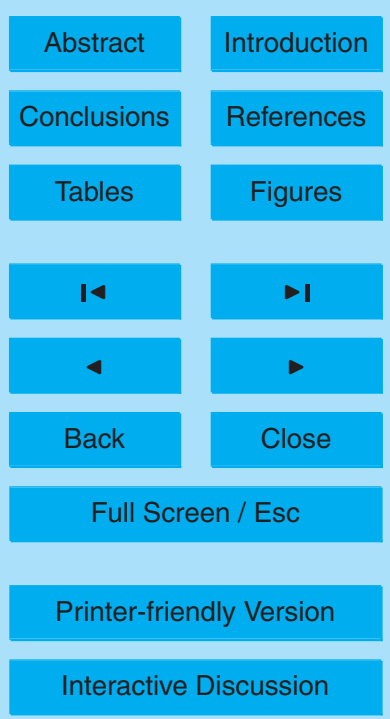




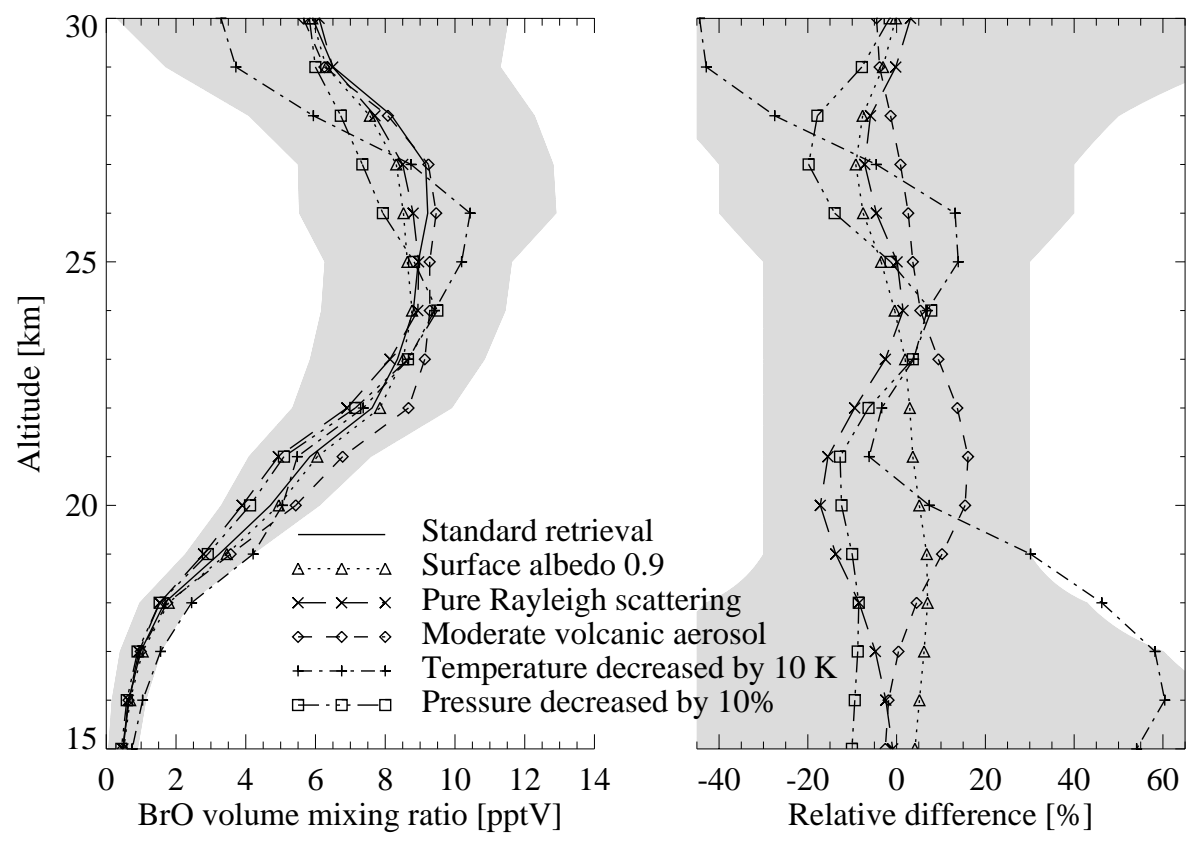

Fig. 1. Dependence of the retrieved vertical distribution of $\mathrm{BrO}$ on the atmospheric composition and surface properties. Left panel: $\mathrm{BrO}$ volume mixing ratio retrieved assuming different input parameters. Right panel: Relative differences of $\mathrm{BrO}$ profiles obtained using perturbed input parameters with respect to the standard retrieval. The shaded area represents the total estimated uncertainty of the retrieved profile.

\section{ACPD}

$6,6431-6466,2006$

\section{BrO from SCIAMACHY}

N. Sheode et al.

Title Page

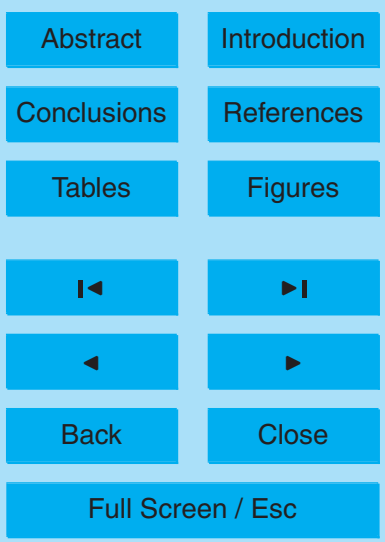

Printer-friendly Version

Interactive Discussion 


\section{ACPD}

\section{$6,6431-6466,2006$}

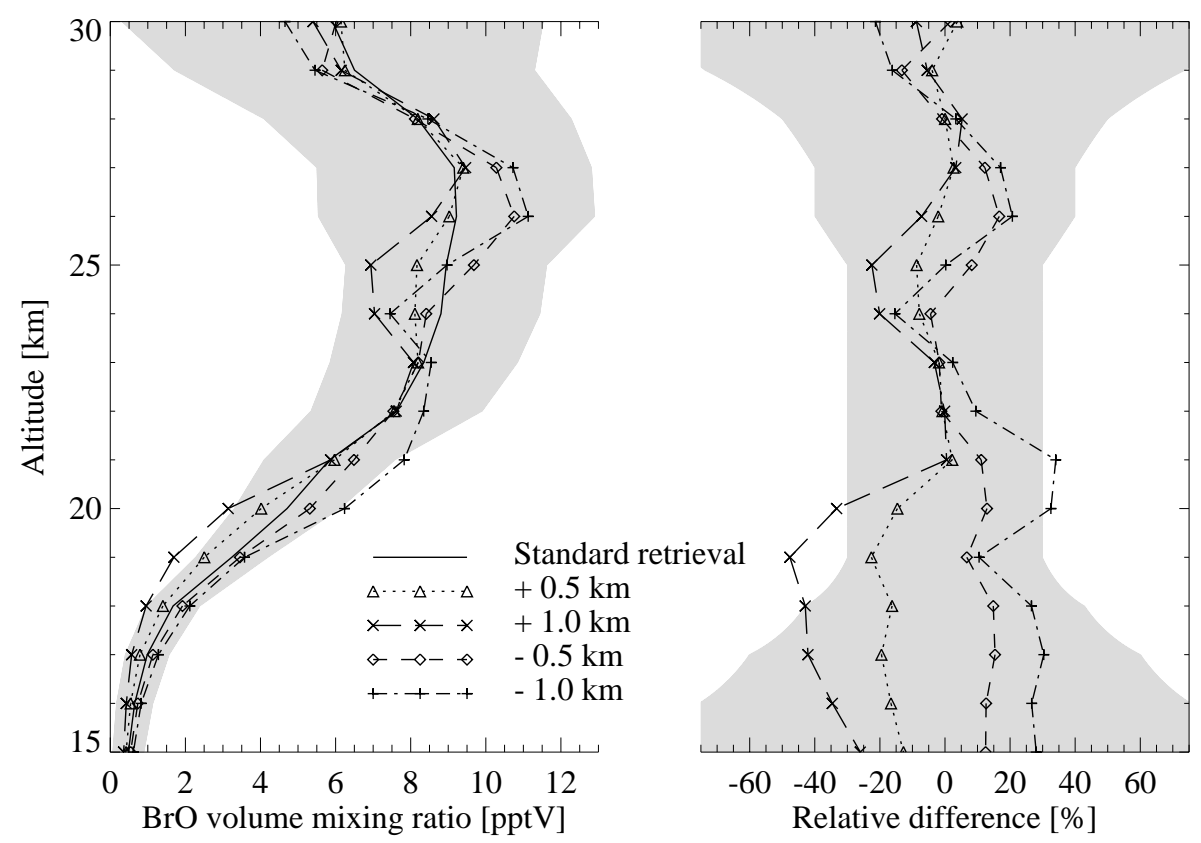

\section{BrO from SCIAMACHY}

N. Sheode et al.

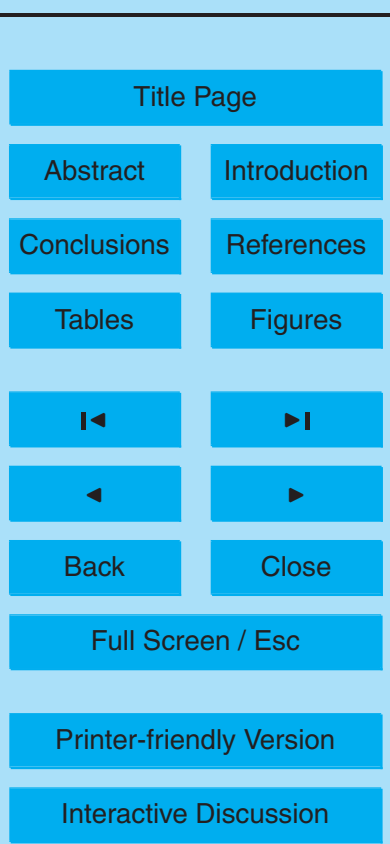

Fig. 2. Influence of the instrument mispointing on the retrieved vertical distribution of BrO. Left panel: BrO volume mixing ratio retrieved assuming different pointing corrections. Right panel: Relative differences of $\mathrm{BrO}$ profiles obtained using pointing corrections with respect to 


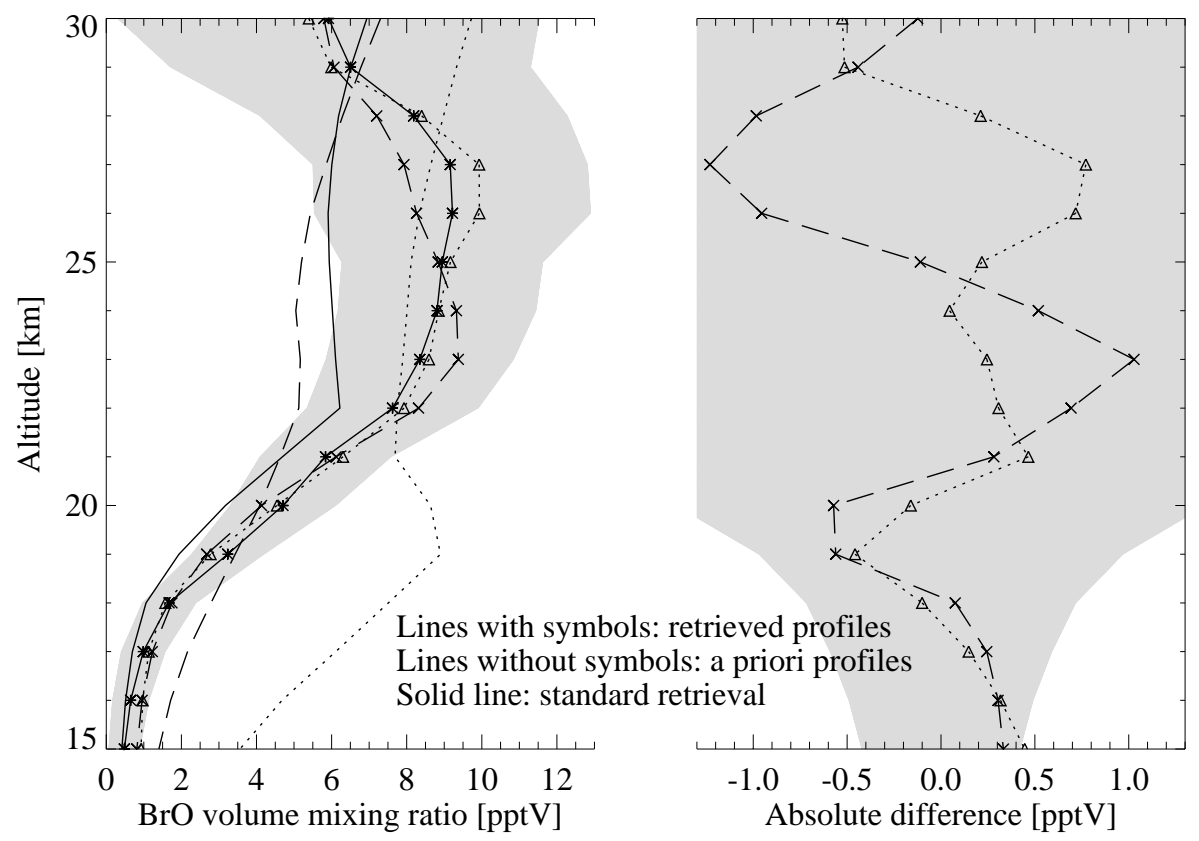

Fig. 3. Influence of a priori information on the retrieved vertical distribution of $\mathrm{BrO}$. Left panel: Curves with symbols show $\mathrm{BrO}$ volume mixing ratio retrieved assuming different a priori profiles shown by the lines of the same type without symbols. Solid line depicts the standard retrieval. Right panel: Absolute differences of $\mathrm{BrO}$ profiles obtained using different a priori profiles with respect to the standard retrieval.

\section{ACPD}

$6,6431-6466,2006$

\section{BrO from SCIAMACHY}

N. Sheode et al.

Title Page

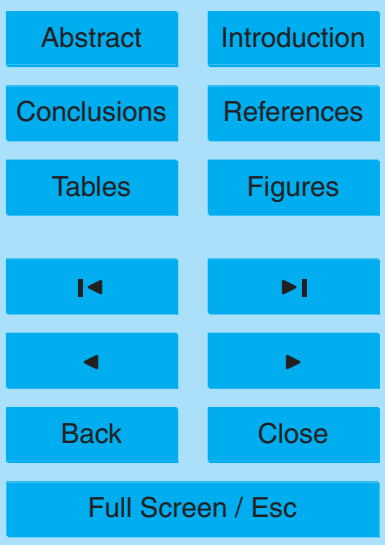

Printer-friendly Version

Interactive Discussion 


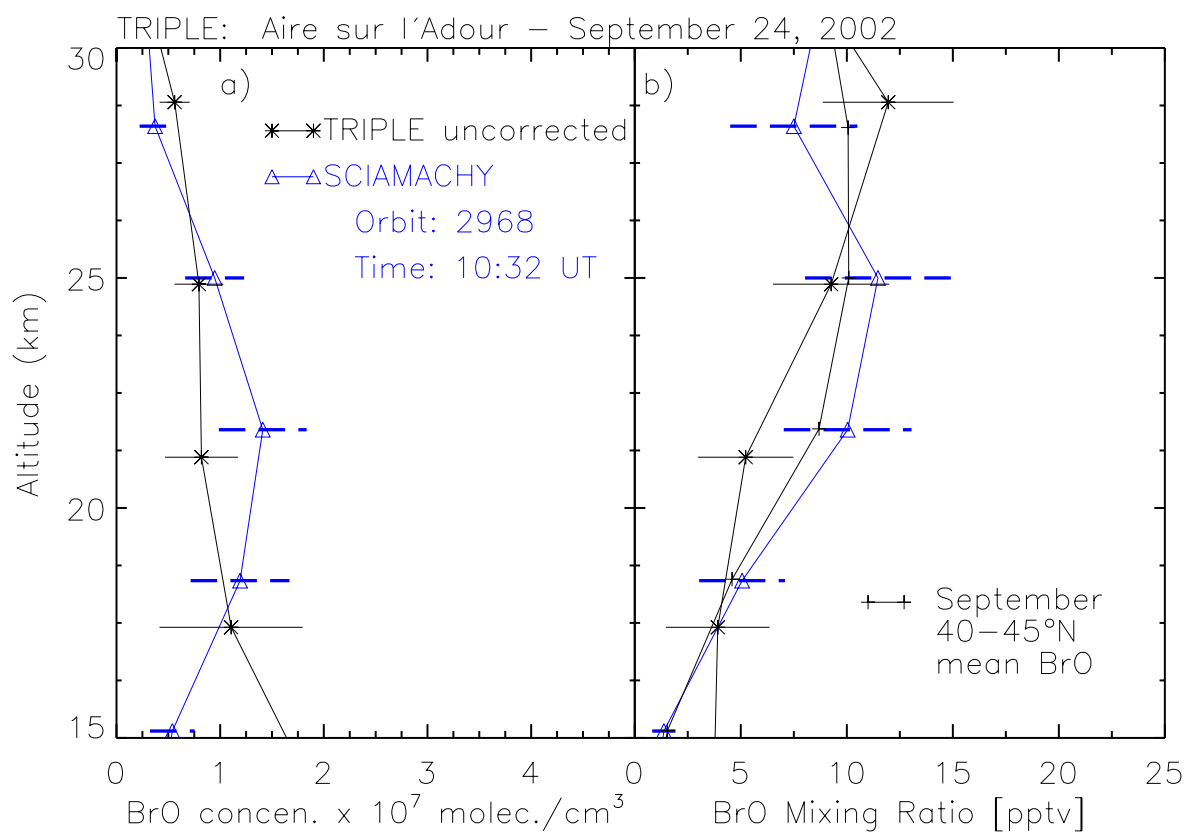

Fig. 4. Comparison of SCIAMACHY BrO retrievals with balloon-borne $\mathrm{BrO}$ observations from the TRIPLE instrument. (a) BrO number density profiles from the TRIPLE flight on 24 September 2002 from Aire sur l'Adure $\left(43.7^{\circ} \mathrm{N}\right.$, balloon $\mathrm{SZA}=60.1^{\circ}$ (a.m.)), together with the corresponding SCIAMACHY profile from Orbit 2968. The retrieval error is approximately $40 \%$ between $15-20 \mathrm{~km}$ and $25-30 \mathrm{~km}$, while it is $30 \%$ between $20-25 \mathrm{~km}$. (b) as in panel (a) but expressed as volume mixing ratio. In addition, the corresponding monthly mean profile from SCIAMACHY for the range from $40^{\circ} \mathrm{N}$ to $45^{\circ} \mathrm{N}$ is shown.
ACPD

$6,6431-6466,2006$

\section{BrO from SCIAMACHY}

N. Sheode et al.

Title Page

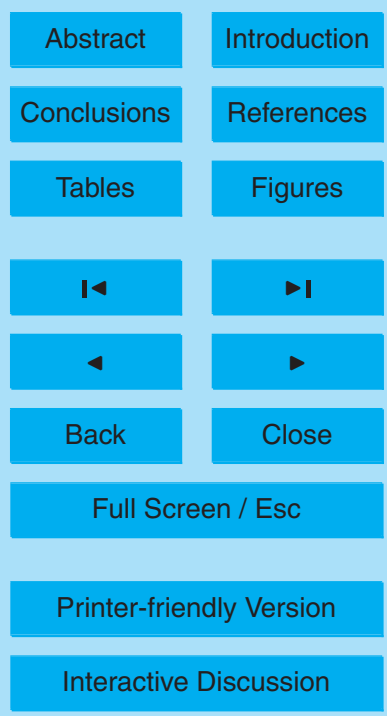




\section{ACPD}

6, 6431-6466, 2006

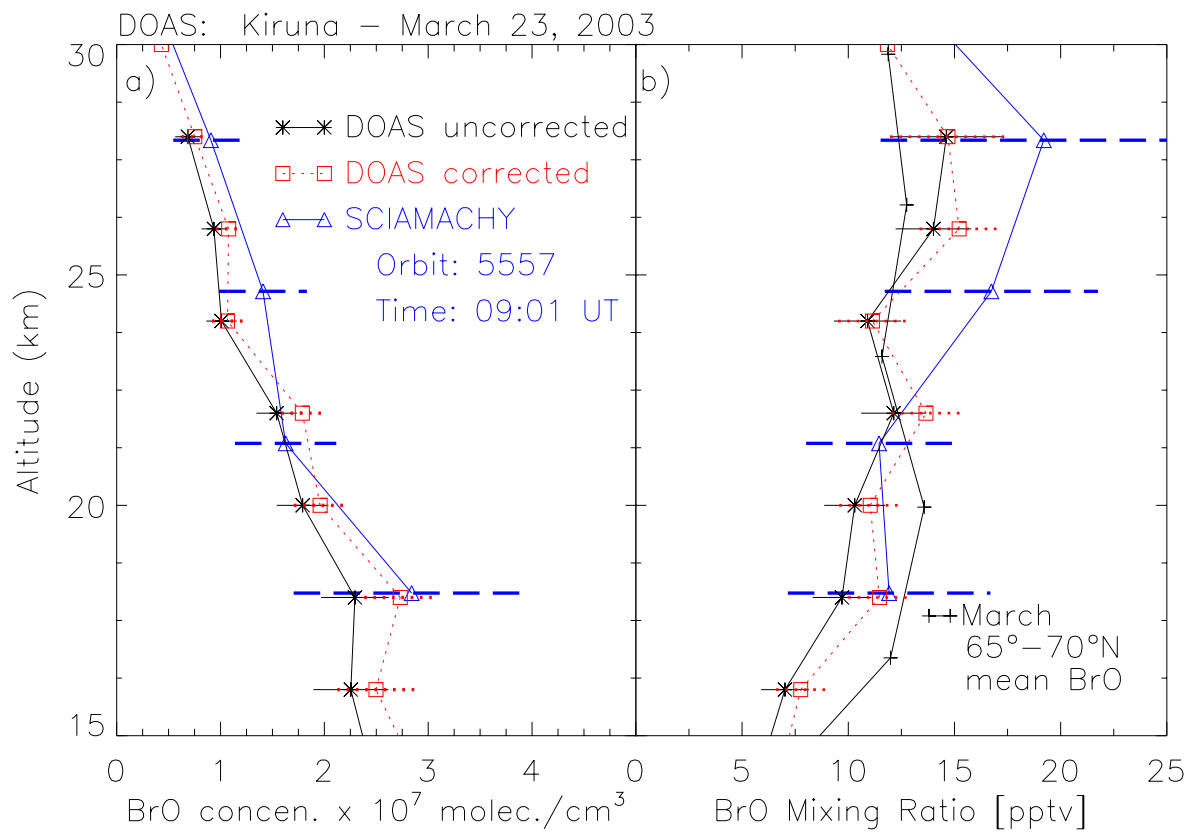

\section{BrO from SCIAMACHY}

N. Sheode et al.

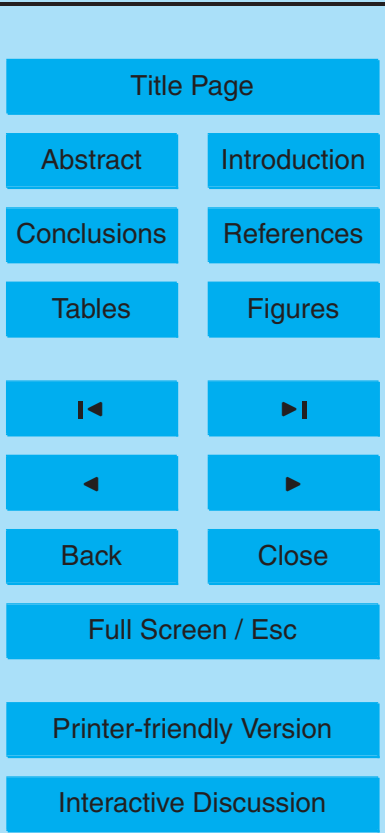




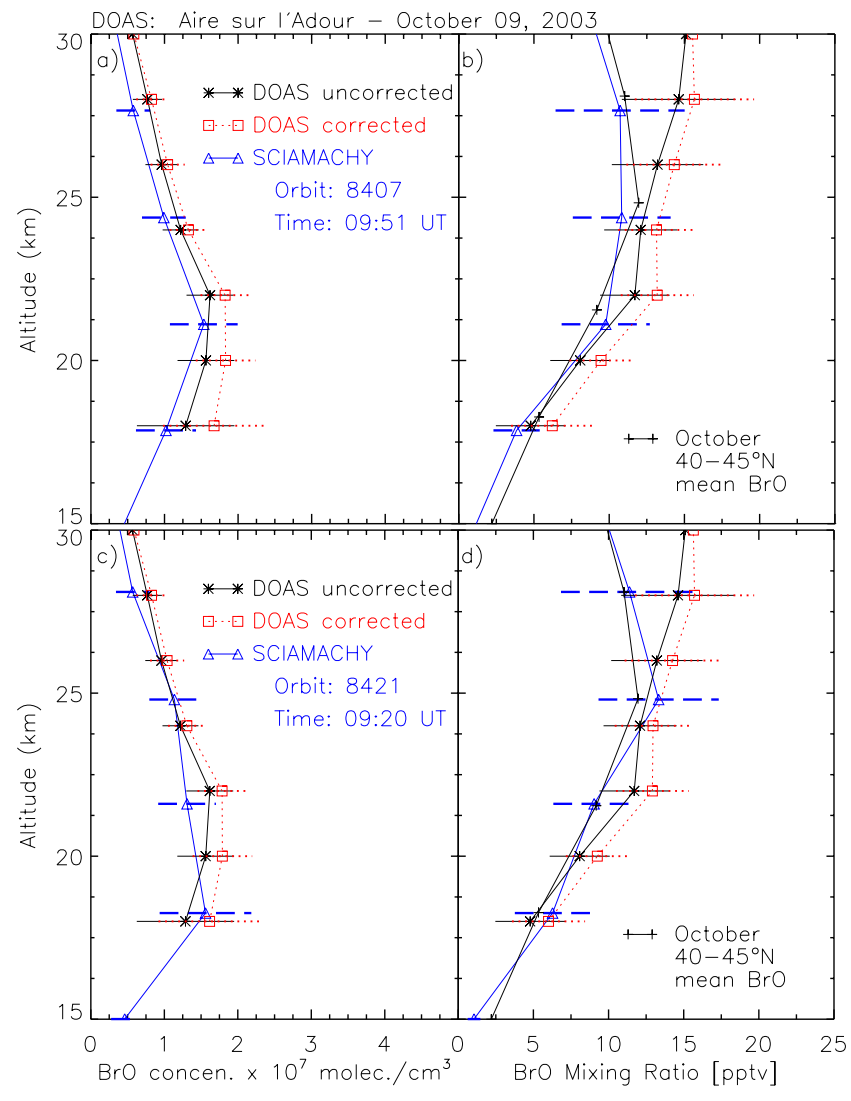

Fig. 6. Same as Fig. 5 but for a comparison with the DOAS balloon flight on 9 October 2003 from Aire sur l'Adure $\left(43.7^{\circ} \mathrm{N}\right.$, balloon SZA $=72.9^{\circ}$ (p.m.)). Panels (a) and (b) show a backward trajectory match, while panels (c) and (d) show a forward trajectory match. See text for details on the trajectory matches.

\section{ACPD}

$6,6431-6466,2006$

\section{BrO from SCIAMACHY}

N. Sheode et al.

Title Page

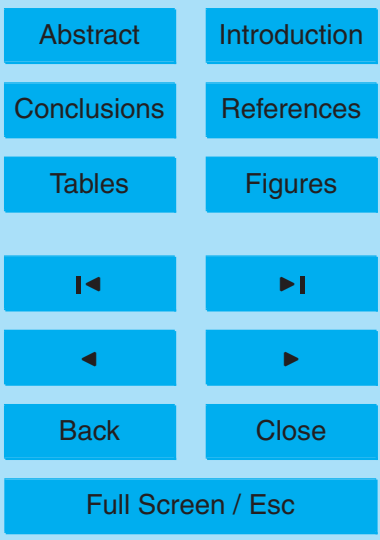

Printer-friendly Version

Interactive Discussion 


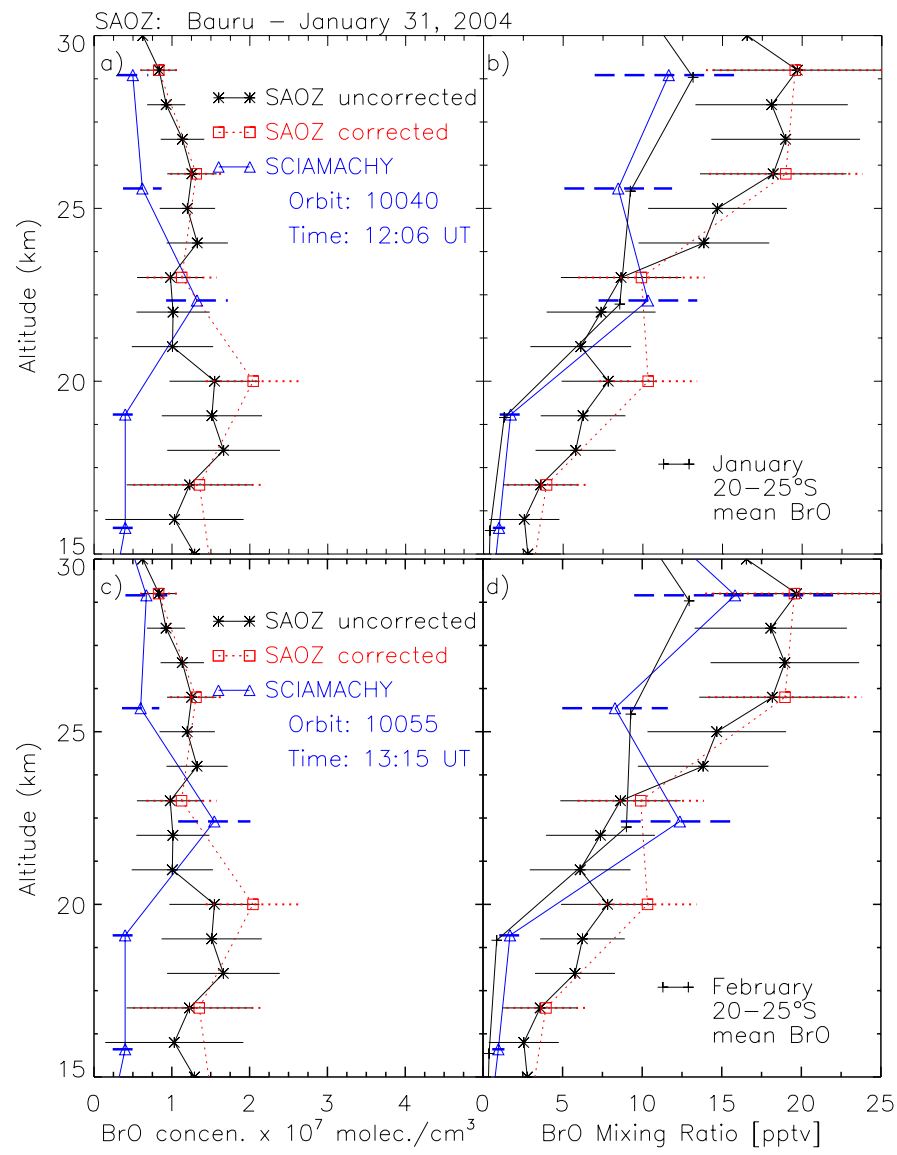

Fig. 7. Same as Fig. 6 but for a comparison with the SAOZ balloon flight on 31 January 2004 from Bauru $\left(22.4^{\circ} \mathrm{S}\right.$, balloon $\mathrm{SZA}=80.2^{\circ}$ (p.m.)).

\section{ACPD}

$6,6431-6466,2006$

\section{BrO from SCIAMACHY}

N. Sheode et al.

Title Page

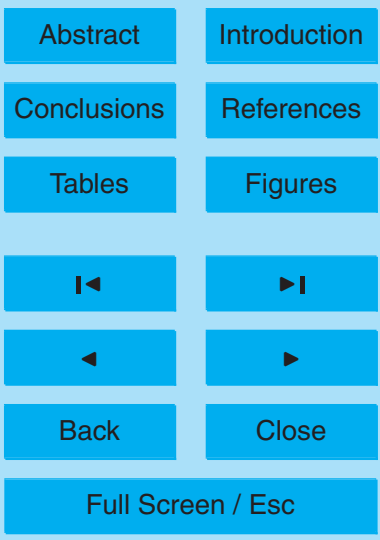

Printer-friendly Version

Interactive Discussion 


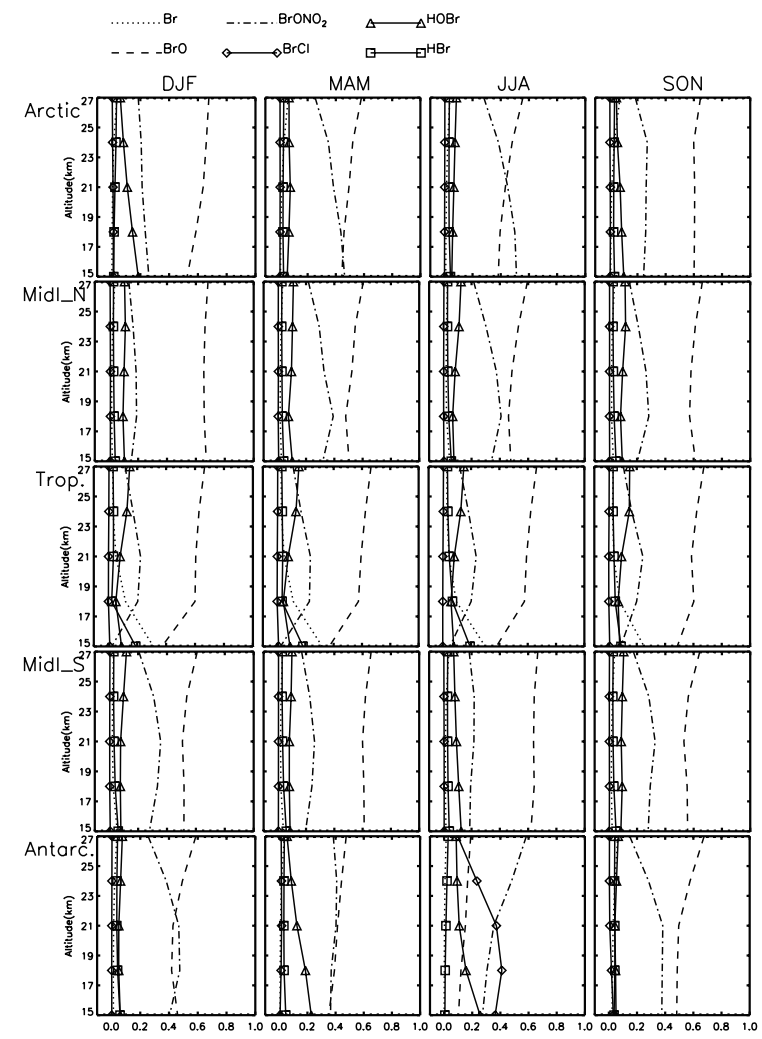

\section{ACPD}

$6,6431-6466,2006$

\section{BrO from SCIAMACHY}

N. Sheode et al.

Title Page

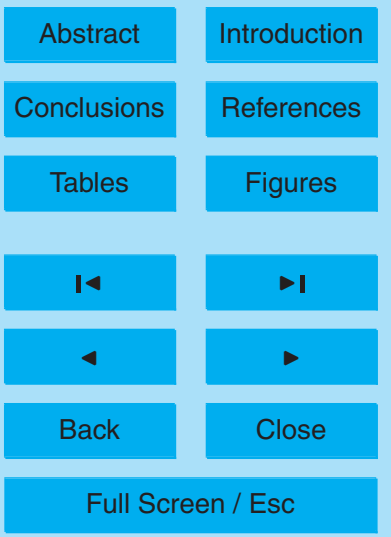

Fig. 8. Partitioning of bromine species as calculated by the 1-D photochemical model. The model was constrained by SCIAMACHY $\mathrm{NO}_{2}$ measurements. Calculations were performed for the four seasons December/January/February (DJF), March/April/May (MAM), June/July/August (JJA) and September/October/November (SON) and five latitude bands: Arctic (north of $\left.60^{\circ} \mathrm{N}\right)$, northern hemisphere mid-latitudes $\left(30^{\circ} \mathrm{N}-60^{\circ} \mathrm{N}\right)$, tropics $\left(30^{\circ} \mathrm{S}-30^{\circ} \mathrm{N}\right)$, southern hemisphere mid-latitudes $\left(30^{\circ} \mathrm{S}-60^{\circ} \mathrm{S}\right)$, and Antarctic (south of $60^{\circ} \mathrm{S}$ ). 

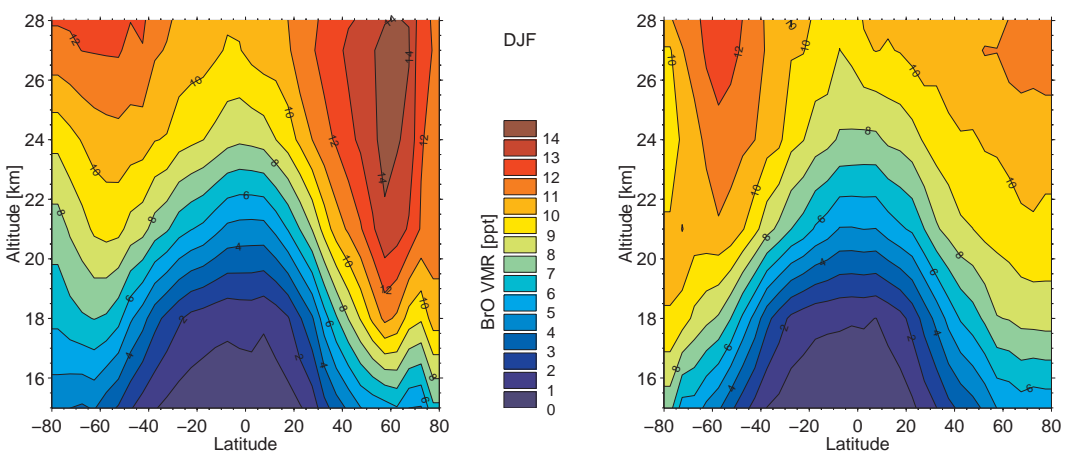

MAM
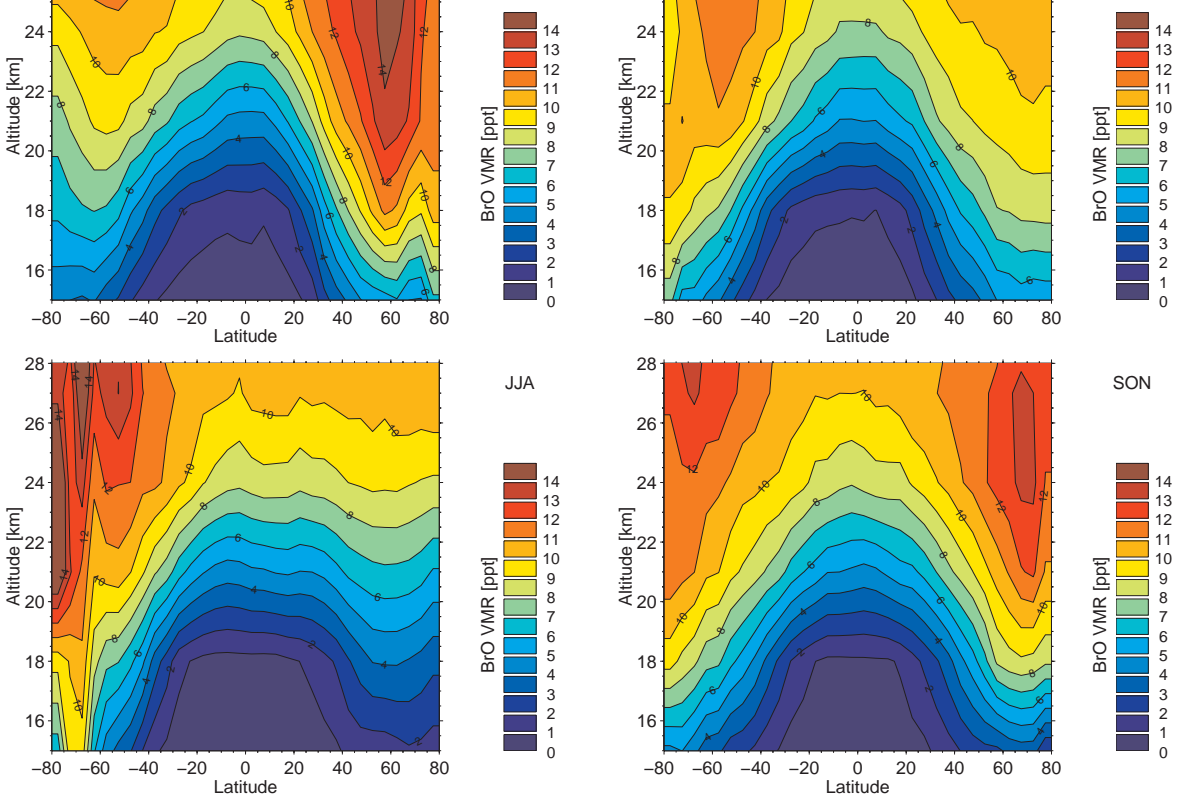

ACPD

$6,6431-6466,2006$

\section{BrO from SCIAMACHY}

N. Sheode et al.

Title Page

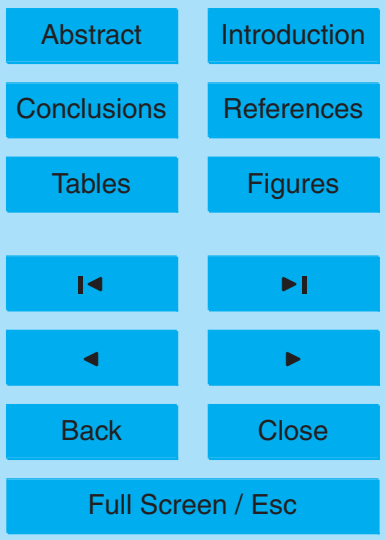

Fig. 9. BrO climatology derived from SCIAMACHY observations during 2003 and 2004. Data have been averaged for the four seasons December/January/February (DJF), March/April/May (MAM) June/July/August (JJA) and September/October/November (SON).

Printer-friendly Version

Interactive Discussion 

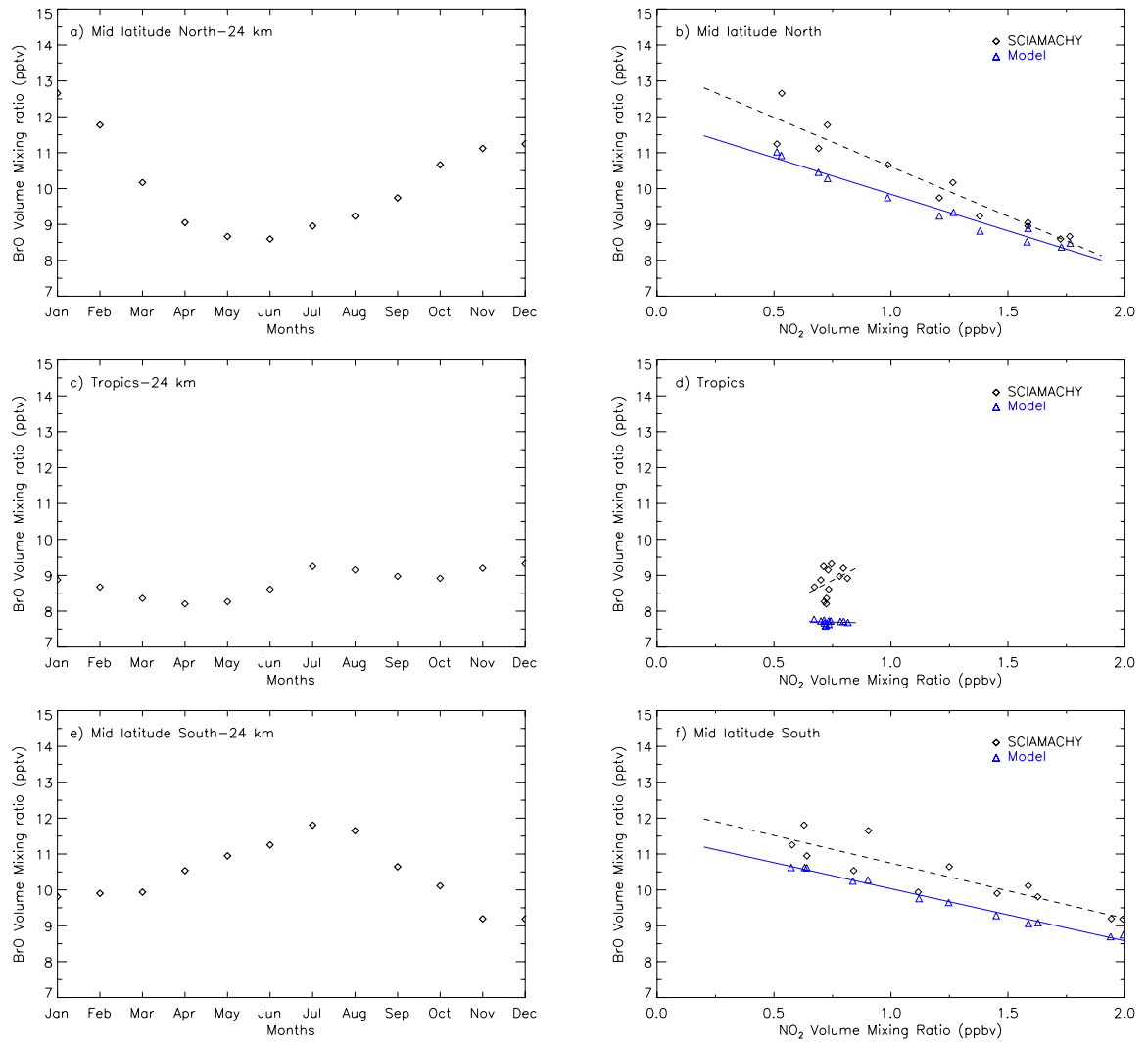

Fig. 10. Seasonal variation of $\mathrm{BrO}$ and its relation to $\mathrm{NO}_{2}$. Panels (a), (c), and (e) show the seasonal variation of $\mathrm{BrO}$ at $24 \mathrm{~km}$ for northern hemisphere mid-latitudes, tropics, and southern hemisphere mid-altitudes, respectively. Panels (b), (d) and (f) show the corresponding relation of $\mathrm{BrO}$ to the observed $\mathrm{NO}_{2}$ mixing ratios. The red points are the data of November and December 2004 which are not used in correlation. For comparison also the relation between $\mathrm{NO}_{2}$ and $\mathrm{BrO}$ from the photochemical model is shown.

\section{ACPD}

$6,6431-6466,2006$

\section{BrO from SCIAMACHY}

N. Sheode et al.

Title Page

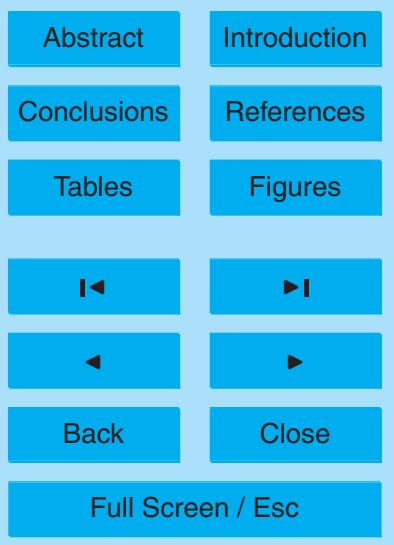

Printer-friendly Version

Interactive Discussion 


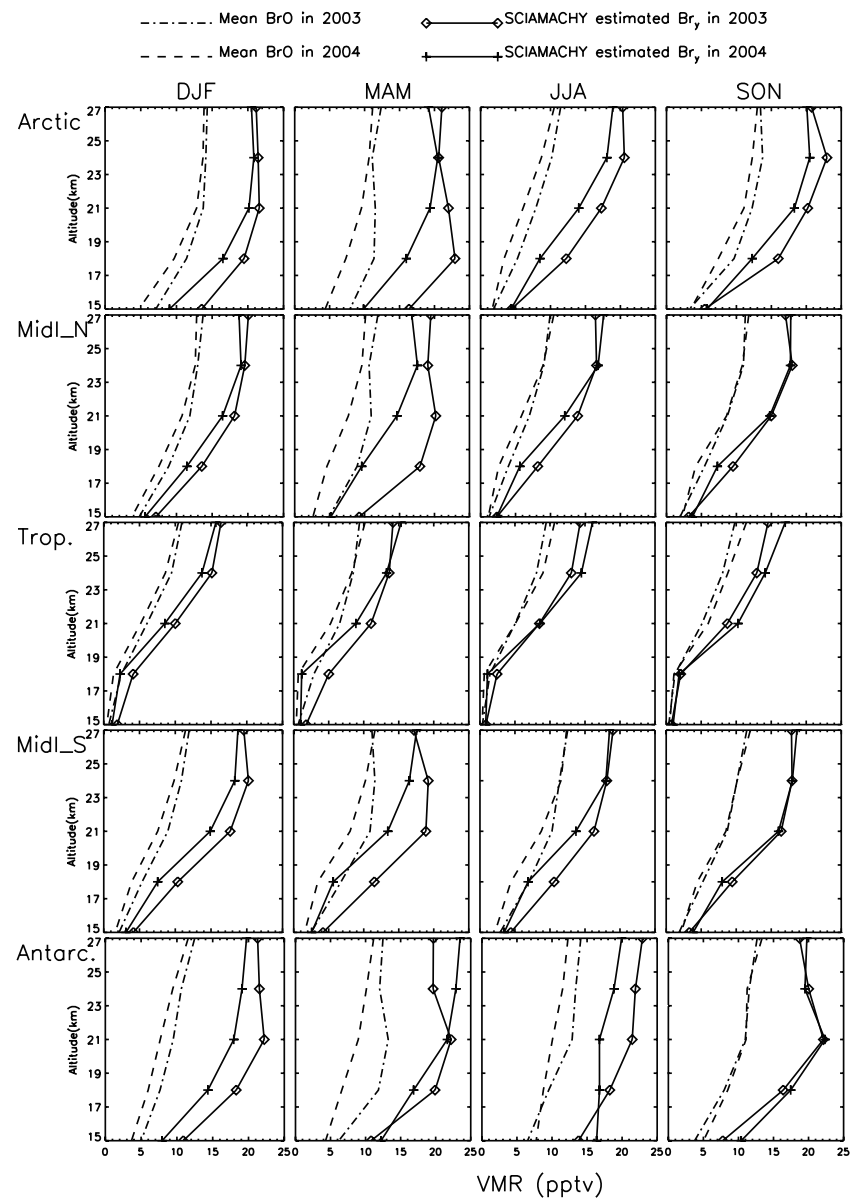

\section{ACPD}

$6,6431-6466,2006$

\section{BrO from SCIAMACHY}

N. Sheode et al.

Title Page

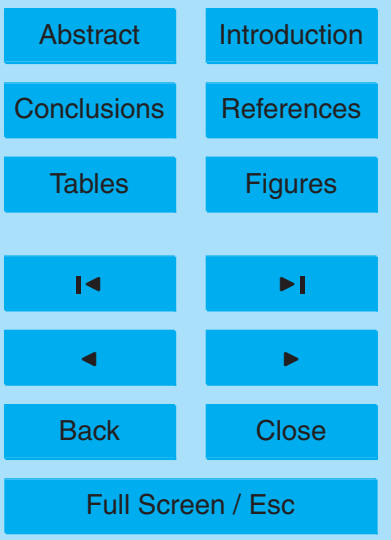

Printer-friendly Version

Interactive Discussion

Fig. 11. Seasonal, zonal mean BrO VMRs for the two years 2003 and 2004 along with estimated $\mathrm{Br}_{\mathrm{y}}$ for the same period. 